\title{
Molecular phylogenetics and classification of Euphorbia subgenus Chamaesyce (Euphorbiaceae)
}

\author{
Ya Yang, ${ }^{1}$ Ricarda Riina, ${ }^{2}$ Jeffery J. Morawetz, ${ }^{3}$ Thomas Haevermans, ${ }^{4}$ Xavier Aubriot ${ }^{4}$ \& Paul E. Berry ${ }^{1,5}$ \\ 1 Department of Ecology and Evolutionary Biology, University of Michigan, Ann Arbor, 830 North University Avenue, Ann Arbor, \\ Michigan 48109-1048, U.S.A. \\ 2 Real Jardín Botánico, CSIC, Plaza de Murillo 2, Madrid 28014, Spain \\ 3 Rancho Santa Ana Botanic Garden, Claremont, California 91711, U.S.A. \\ 4 Muséum National d'Histoire Naturelle, Département Systématique et Evolution, UMR 7205 CNRS/MNHN Origine, Structure \\ et Evolution de la Biodiversité, CP 39, 57 rue Cuvier, 75231 Paris cedex 05, France \\ 5 University of Michigan Herbarium, Department of Ecology and Evolutionary Biology, 3600 Varsity Drive, Ann Arbor, \\ Michigan 48108, U.S.A. \\ Author for correspondence: Paul E. Berry, peberry@umich.edu
}

\begin{abstract}
Euphorbia subg. Chamaesyce contains around 600 species and includes the largest New World radiation within the Old World-centered genus Euphorbia. It is one of the few plant lineages to include members with $\mathrm{C}_{3}, \mathrm{C}_{4}$ and CAM photosynthesis, showing multiple adaptations to warm and dry habitats. The subgenus includes North American-centered groups that were previously treated at various taxonomic ranks under the names of "Agaloma", "Poinsettia", and "Chamaesyce". Here we provide a well-resolved phylogeny of Euphorbia subg. Chamaesyce using nuclear ribosomal ITS and chloroplast $n d h F$ sequences, with substantially increased taxon sampling compared to previous studies. Based on the phylogeny, we discuss the Old World origin of the subgenus, the evolution of cyathial morphology and growth forms, and then provide a formal sectional classification, with descriptions and species lists for each section or subsection we recognize.
\end{abstract}

Key Words $\mathrm{C}_{4}$; CAM; Euphorbia subgenus Chamaesyce; Euphorbiaceae; ITS; $n d h F$

Supplementary Material The alignment files are available in the Supplementary Data section of the online version of this article (http://www.ingentaconnect.com/content/iapt/tax).

\section{INTRODUCTION}

Euphorbia L. (Euphorbiaceae) has about 2000 species worldwide and is well known for the remarkable diversity of succulent and non-succulent plants that are avidly grown by horticultural enthusiasts. The entire genus is characterized by the presence of a cyathium, a unique inflorescence type (Prenner \& Rudall, 2007; Prenner \& al., 2011). The genus appears to have originated in the Old World (Steinmann \& Porter, 2002), with multiple New World groups embedded in it. The largest New World lineage consists of more than 500 species that are characterized by the presence of petaloid appendages subtending the cyathial glands, although this feature has been subsequently lost a number of times. This petaloid appendagebearing, New World group is deeply nested within Old World groups, and together they constitute Euphorbia subg. Chamaesyce Raf. (Steinmann \& Porter, 2002; Bruyns \& al., 2006; Horn \& al., 2012a). Subgenus Chamaesyce is best known for its leafy, non-succulent, ornamental species, such as the Christmas Poinsettia (E. pulcherrima Willd. ex Klotzsch), one of the most profitable potted plants in the world. Other widely cultivated members are "Snow-on-the-Mountain" (E. marginata Pursh.) and "Diamond Frost" (a cultivar of E. graminea Jacq.). It also includes a large number of cosmopolitan weedy species such as the spotted spurge (E. maculata L., Fig. 1E).
Among the four subgenera of Euphorbia, Euphorbia subg. Chamaesyce is the second-most species-rich, encompassing around 600 species worldwide. It is highly diverse in growth forms, including annual and perennial herbs, shrubs, trees, and pencil-stem succulents (Fig. 1A-E). Notably, it is the only plant lineage at or below the level of genus that has all known photosynthetic types: $\mathrm{C}_{3}, \mathrm{C}_{4}$ and CAM (Webster \& al., 1975), plus a $\mathrm{C}_{2}$ system that represents an early stage of $\mathrm{C}_{3}$ to $\mathrm{C}_{4}$ transition (Sage \& al., 2011). $\mathrm{C}_{4}$ photosynthesis evolved once within Euphorbia subg. Chamaesyce sect. Anisophyllum, and this $\mathrm{C}_{4}$ group subsequently diversified into approximately 350 species worldwide (Yang \& Berry, 2011); $\mathrm{C}_{2}$ photosynthesis also evolved once, again in sect. Anisophyllum, and is present in two species restricted to southwestern United States and northern Mexico (Sage \& al., 2011). CAM photosynthesis, in contrast, evolved multiple times in subg. Chamaesyce in both the Old World and the New World (Horn \& al., 2012b).

Due to widespread convergence in growth forms and cyathial characters, subgeneric classification within Euphorbia has been notoriously contentious. The current scheme of four subgenera is based on molecular evidence. All molecular phylogenetic studies to date support all cyathium-bearing species as forming a monophyletic Euphorbia s.l. (Steinmann \& Porter, 2002; Bruyns \& al., 2006, 2011; Park \& Jansen, 2007; Zimmermann \& al., 2010; Horn \& al., 2012a). These studies 
also support the monophyly of four major clades within Euphorbia, which were informally named by Steinmann \& Porter (2002) as clades A, B, C and D. Among them, clade D was later recognized by Bruyns \& al. (2006) as subg. Chamaesyce Raf. These studies either have limited taxon sampling within subg. Chamaesyce, or else they have low statistical support within subg. Chamaesyce. Steinmann \& Porter (2002) sampled 82 of the 600 species in subg. Chamaesyce for nuclear ribosomal internal transcribed spacer (ITS), among which 40 also had $n d h F$ sequences. Using maximum parsimony, they found that the majority of deep nodes within the genus received low statistical support. Four subsequent genus-wide molecular phylogenetic studies each added only a small number of species within subg. Chamaesyce, and relationships among major groups of the subgenus remained poorly supported (Bruyns \& al., 2006, 2011; Park \& Jansen, 2007; Zimmermann \& al., 2010). This problem was partly addressed by the "backbone" phylogeny of Horn \& al. (2012a), which sampled 176 species across Euphorbia using ten loci, including nuclear, mitochondrial and chloroplast regions, with 31 representative species within subg. Chamaesyce. This study had much improved support values within subg. Chamaesyce, and it highly supported the monophyly of subg. Chamaesyce, as well as its sister relationship to Euphorbia subg. Euphorbia. Of all six previous genus-wide molecular studies, three of them support a monophyletic, primarily New World clade nested in a basal Old World grade (Steinmann \& Porter, 2002; Zimmermann \& al., 2010; Horn \& al., 2012a). The other three studies lack statistical support for deep nodes within subg. Chamaesyce (Bruyns \& al., 2006, 2011; Park \& Jansen, 2007). In addition to these studies, Yang \& Berry (2011) constructed a robust phylogeny of Euphorbia subg. Chamaesyce sect. Anisophyllum, which corresponds to the former segregate genus Chamaesyce S.F. Gray. In their analysis, 138 ingroup species were sequenced with two nuclear loci and three chloroplast loci, and the monophyly of sect. Anisophyllum was well supported. Taking all seven previous molecular studies into account, about a third of the species in subg. Chamaesyce were sampled, and most species outside of sect. Anisophyllum only have ITS sequences available.

With the international collaborative network established by the Euphorbia Planetary Biodiversity Inventory (Euphorbia PBI) project (www.euphorbiaceae.org), we have been able to greatly expand our worldwide taxon sampling to reconstruct a well-sampled, and well-supported molecular phylogeny. The main purpose of this paper is to propose a revised sectional and subsectional classification of Euphorbia subg. Chamaesyce in light of the updated phylogeny we have produced. This will provide a stable nomenclatural base for subsequent research.

\section{MATERIALS AND METHODS}

Taxon sampling. - Silica-preserved leaf samples were collected in all major areas where Euphorbia occurs during 2006-2009. Sampling was supplemented by leaf materials taken from herbarium sheets. To include as many taxa as possible belonging to subg. Chamaesyce, we conducted a preliminary maximum parsimony analysis in PAUP* (Swofford, 2003), using $n d h F$ sequences to assign each taxon to one of the four subgenera in Euphorbia. In addition, all sequences in GenBank that belong to subg. Chamaesyce were included. In total, our taxon sampling covered 291 out of the total of 600 species in the subgenus, with all previously recognized sections and most subsections represented. Since the monophyly and subclade structure within sect. Anisophyllum was well established in an earlier study (Yang \& Berry, 2011), we reduced taxon sampling within sect. Anisophyllum to 15 species representing all major subclades. About 80 DNA accessions that grouped together with conspecific sequences during our preliminary analysis were excluded. In total, our final matrices include 174 taxa (163 ingroup taxa and 11 species representing the other three subgenera of Euphorbia as outgroups). All taxa sampled for the molecular phylogeny are associated with herbarium voucher specimens and are listed in the Appendix.

DNA extraction, amplification, and sequencing. - DNA extraction and PCR amplification of the ITS region were carried out following Yang \& Berry (2011). The chloroplast $N A D H$ dehydrogenase $F(n d h F)$ coding region was PCR-amplified in two pieces: the $5^{\prime}$ half was amplified using primers 536 and 1318R (Olmstead \& Sweere, 1994), and the 3' half using primers 972 (Olmstead \& Sweere, 1994) and 2110Ri (Steinmann \& Porter, 2002). The PCR mixture contained $0.15 \mu \mathrm{L}$ of 5 units $/ \mu \mathrm{L}$ Ex Taq (Takara Bio Inc., Otsu, Shiga, Japan), $2.5 \mu \mathrm{L} 10 \times E x$ Taq Buffer, $2.0 \mu \mathrm{L}$ dNTP $(2.5 \mathrm{mM}), 1.0 \mu \mathrm{L}$ of each primer $(10$ $\mu \mathrm{M}), 2 \mu \mathrm{L}$ of diluted template DNA (dilution varies from $1 / 20$ to $1 / 80$ ), and $\mathrm{ddH}_{2} \mathrm{O}$ to bring the final volume to $25 \mu \mathrm{L}$. The PCR profile consisted of an initial 4 min denaturing step at $95^{\circ} \mathrm{C}$ followed by 40 cycles of $45 \mathrm{~s}$ denaturing at $95^{\circ} \mathrm{C}, 45 \mathrm{~s}$ annealing at $53.6^{\circ} \mathrm{C}$, and 2 min "slow and cold" extension at $65^{\circ} \mathrm{C}$ (Shaw \& al., 2007). PCR products were purified with ExoSap-IT (USB Corporation, Cleveland, Ohio, U.S.A.), or QIAquick PCR Purification Kit (Qiagen, Valencia, California, U.S.A.). Cleaned PCR products were sequenced at the University of Michigan DNA Sequencing Core using the respective PCR primers.

Phylogenetic analyses. - Chromatograms were assembled and edited in the program Sequencher v.4.10.1 (Gene Codes, Ann Arbor, Michigan, U.S.A.). Sequence alignments were performed in the program MUSCLE v.3.8 (Edgar, 2004) using the default parameters, and manually adjusted in the program MacClade v.4.08 (Simmons, 2004; Maddison \& Maddison, 2005). The full-length data matrices are in the online supplementary data, and sequences are deposited in GenBank (Appendix).

Phylogenetic analyses using maximum likelihood (ML) and Bayesian inference (BI) were conducted on the ITS and $n d h F$ matrices separately, with gaps treated as missing data. Congruence between the resulting ITS and $n d h F$ trees was visually inspected before concatenating them into a combined matrix. ITS, $n d h F$ and the combined matrices were each subjected to the analyses described below.

Maximum likelihood analyses were carried out in the program RAxML v.7.0.3 (Stamatakis, 2006), partitioning ITS vs. $n d h F$ regions. The nucleotide substitution model was set to 

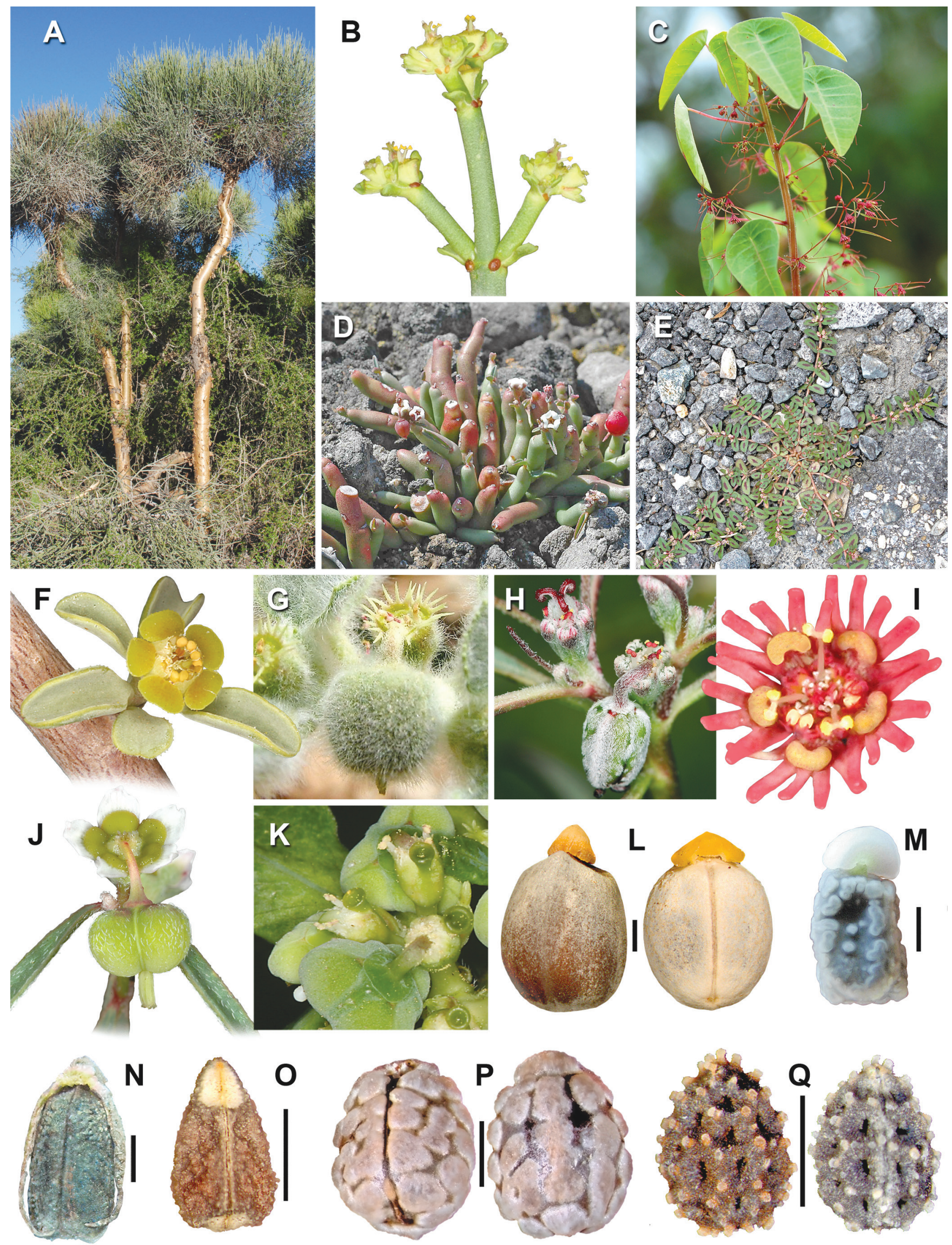
$\mathrm{GTR}+\mathrm{G}$ as recommended by the RAxML manual; $500 \mathrm{ML}$ bootstrap replicates were performed, followed by a thorough search for the best tree. Bayesian inference was conducted in the program MrBayes v.3.1.2 (Huelsenbeck \& Ronquist, 2001; Ronquist \& Huelsenbeck, 2003). Two independent runs (four for the combined dataset) of four chains each (three heated, one cold), starting from random trees, using the default temperature of 0.2 , were run for 15 million generations. Trees were sampled every 1000 generations. Each analysis was conducted using the nucleotide substitution model GTR $+\mathrm{I}+\mathrm{G}$ as selected by Akaike information criterion (AIC) in the program MrModeltest v.2.3 (Nylander, 2004). To prevent unrealistically long branches, "br lenspr=unconstrained:exponential(100.0)" was applied (Brown $\&$ al., 2010; Marshall, 2010). The relevant parameters for convergence were visually examined in the program Tracer v.1.5 (Rambaut \& Drummond, 2007) to verify stationary status. Trees from the first 2.5 million generations were discarded as burn-in; the remaining trees were used to compute the majorityrule consensus tree and support statistics.

\section{口 RESULTS}

Overall statistics of the gene regions sequenced for this study are summarized in Table 1. Results of phylogenetic analyses are shown in Figs. 2 and 3 and are summarized in Fig. 4. For each of the three analyses (ITS, $n d h F$, combined ITS $+n d h F$ ), $\mathrm{BI}$ and ML results are congruent for nodes with ML bootstrap support (MLB) $\geq 50$ and Bayesian posterior probability (PP) $\geq 0.80$; monophyly of subg. Chamaesyce and its sister relationship to Euphorbia subg. Euphorbia are both highly supported $(\mathrm{MLB} \geq 80 ; \mathrm{PP}=1)$. Groups are numbered consistently across
Figs. 2-4, and labels for sections, subsections, and subclades are shown on the combined tree only in Fig. 3.

ITS dataset. - The ITS dataset has a relatively high proportion of variable sites compared to $n d h F(71.1 \%$ vs. $45.1 \%$, Table 1). The alignment required some manual adjustment in parts, and all characters were included in the subsequent phylogenetic analysis. Monophyly of each section is strongly supported by MLB $\geq 70$ (not shown) and PP $=1$ (Fig. 2), except that sect. Gueinziae (11) is nested in sect. Crossadenia (12) with $\mathrm{MLB}=72$ (not shown) and PP $=0.81$.

ndhF dataset. - The $n d h F$ coding region could be unambiguously aligned, with relatively fewer variable sites compared to ITS (Table 1). Monophyly of each section is supported by MLB $\geq 81$ (not shown) and PP $\geq 0.88$ (Fig. 2), except for sect. Poinsettia, where E. jaliscensis is sister to sect. Poinsettia (14) + sect. Alectoroctonum (15) with MLB $=62$ (not shown) and $\mathrm{PP}=0.75$ (Fig. 2).

Combined ITS $+\boldsymbol{n d h} \boldsymbol{F}$ dataset. - Analysis of the combined dataset produced a well-resolved phylogeny (Fig. 3). Monophyly of each section is supported by MLB $\geq 92$ and PP $\geq$ 0.92, except for sect. Crossadenia, which has sect. Gueinziae nested within it. Relationships within each clade are well resolved in general, except for certain nodes in sect. Alectoroctonum and sect. Articulofruticosae. There are five instances of moderately (thin continuous lines) to strongly supported (thick lines) incongruence between the ITS and $n d h F$ datasets, and such incongruences affect the combined analysis in different ways (Figs. 2, 3). (1) In sect. Alectoroctonum, the two clades marked with an asterisk $(*)$ are strongly supported as sister to each other in the combined analysis and in the $n d h F$ phylogeny, while ITS strongly supports them forming a paraphyletic grade. (2) Euphorbia jaliscensis is strongly supported as nested

Table 1. Summary statistics for the aligned molecular data matrices.

\begin{tabular}{llll}
\hline & $n d h F$ & ITS & combined $n d h F+$ ITS \\
\hline No. of accessions & 147 & 172 & 182 \\
Range of raw length ${ }^{\mathrm{a}}[\mathrm{bp}]$ & $762-1480$ & $336-651$ & $584-2123$ \\
Aligned length & 1547 & 714 & 2261 \\
Variable characters (proportion) & $697(45.1 \%)$ & $508(71.1 \%)$ & $1205(53.3 \%)$ \\
\hline
\end{tabular}

${ }^{a}$ Lower ends of raw lengths are from partial sequences that the full-length sequences failed to amplify or sequence.

\footnotetext{
Fig. 1. Euphorbia subg. Chamaesyce: A-E, representative growth forms; F-K, cyathial morphologies; L-Q, seed morphologies. A, Euphorbia plagiantha, a broom-like tree (sect. Plagianthae; Dorsey 164, MICH); B, E. burmannii, a stem-succulent shrub with opposite or dichotomous branching and terminal cymes (sect. Articulofruticosae; Becker \& Moller 1141, UNIN); C, E. subpeltata, a herb with indeterminate main shoots and axillary cymes (sect. Alectoroctonum; Steinmann 5585, IEB); D, E. gumaroi, a stem-succulent herb with alternate branching and single, terminal cyathia (sect. Alectoroctonum; Steinmann 5813, MICH); E, E. maculata, a prostrate herb with early termination of main shoots typical of sect. Anisophyllum; F, E. guerichiana, showing exappendiculate glands (sect. Espinosae; Becker \& Moller 929, UNIN); G, E. petiolata, showing pectinate cyathial glands (sect. Cheirolepidium; Zarre \& Salmaki 39514, TUH); H, E. eriantha, showing gland appendages arching over and concealing the glands (sect. Erianthae; field photo, California); I, E. subpeltata, showing cyathial appendages with finger-like lobes (sect. Alectoroctonum; Steinmann 5585, IEB); J, E. sphaerorhiza, showing cyathial morphology typical in sect. Alectoroctonum (Yang 110, MICH); K, E. heterophylla, showing single, stalked and cupped glands typical of sect. Poinsettia subsect. Stormieae (Riina 1825, VEN); L, E. espinosa (sect. Espinosae; Leach 15938, UNIN); M, E. petiolata (sect. Cheirolepidium; Zarre \& Salmaki 39514, TUH); N, E. cheirolepis (sect. Cheirolepidium); 0, E. mundii (sect. Articulofruticosae; Leach 17110, UNIN); P, E. goyazensis (sect. Crossadenia; Caruzo 139, HUEFS); Q, E. sonorae (sect. Alectoroctonum; Fishbein 2455, RSA). - Photo credits: A, B.L. Dorsey; B \& F, A. Moller; C, D, I \& J, V.W. Steinmann; E, P.E. Berry; G \& M, Y. Salmaki and S. Zarre; H, S. Matson; K, R. Riina; L, O \& Q, B. Wagner; N, A.H. Pahlevani; P, J.J. Morawetz.
} 
within sect. Poinsettia in the combined analysis and with ITS, but not with the $n d h F$ data alone. (3) Euphorbia gueinzii is nested within sect. Crossadenia in the ITS analysis with strong support, while $n d h F$ provides low support (dashed line) for E. gueinzii being sister to sect. Crossadenia; the combined analysis is congruent with the ITS topology in this case but with weaker support values. (4) Euphorbia salota is strongly supported by the combined and $n d h F$ analyses to be nested within the Madagascar clade, while ITS places it sister to sect. Cheirolepidium + sect. Eremophyton with moderate support, separated from the rest of the Madagascan species. (5) Within sect. Articulofruticosae, results from ITS either conflict with $n d h F$ or are poorly resolved, and the combined tree is also poorly resolved.

\section{DISCUSSION}

Our results are consistent with all six previous genus-wide molecular phylogenetic studies and support subg. Chamaesyce being monophyletic and sister to subg. Euphorbia (Steinmann \& Porter, 2002; Bruyns \& al., 2006, 2011; Park \& Jansen, 2007;
Zimmermann \& al., 2010; Horn \& al., 2012a). Three of these six previous studies supported a single origin of New World taxa from an Old World grade within subg. Chamaesyce, with the eastern Brazilian clade sect. Crossadenia being sister to the rest of the New World group (Steinmann \& Porter, 2002; Zimmermann \& al., 2010; Horn \& al., 2012a). Our results differ somewhat in that they support an Old World-eastern Brazilian clade sister to a New World clade, and together these are nested in a paraphyletic Old World grade (Fig. 4).

Bruyns \& al. (2006) made an attempt to provide a sectional classification of subg. Chamaesyce based on molecular data. They recognized four sections within the subgenus: (1) "sect. Chamaesyce", which included the New World clade+Old World-eastern Brazilian clade+sect. Tenellae, sharing petaloid cyathial appendages (the "petaloid appendage clade", Fig. 4; Horn \& al., 2012a); (2) sect. Frondosae, a diverse Old World group; (3) sect. Articulofruticosae, a group of pencil-stem succulents from southern Africa that is both molecularly and morphologically distinct; and (4) sect. Espinosae, a clade of two shrubby or tree-forming species from Africa; they left E. tannensis unplaced. Among the four sections that they recognized, we agree with their naming and circumscription for all but the
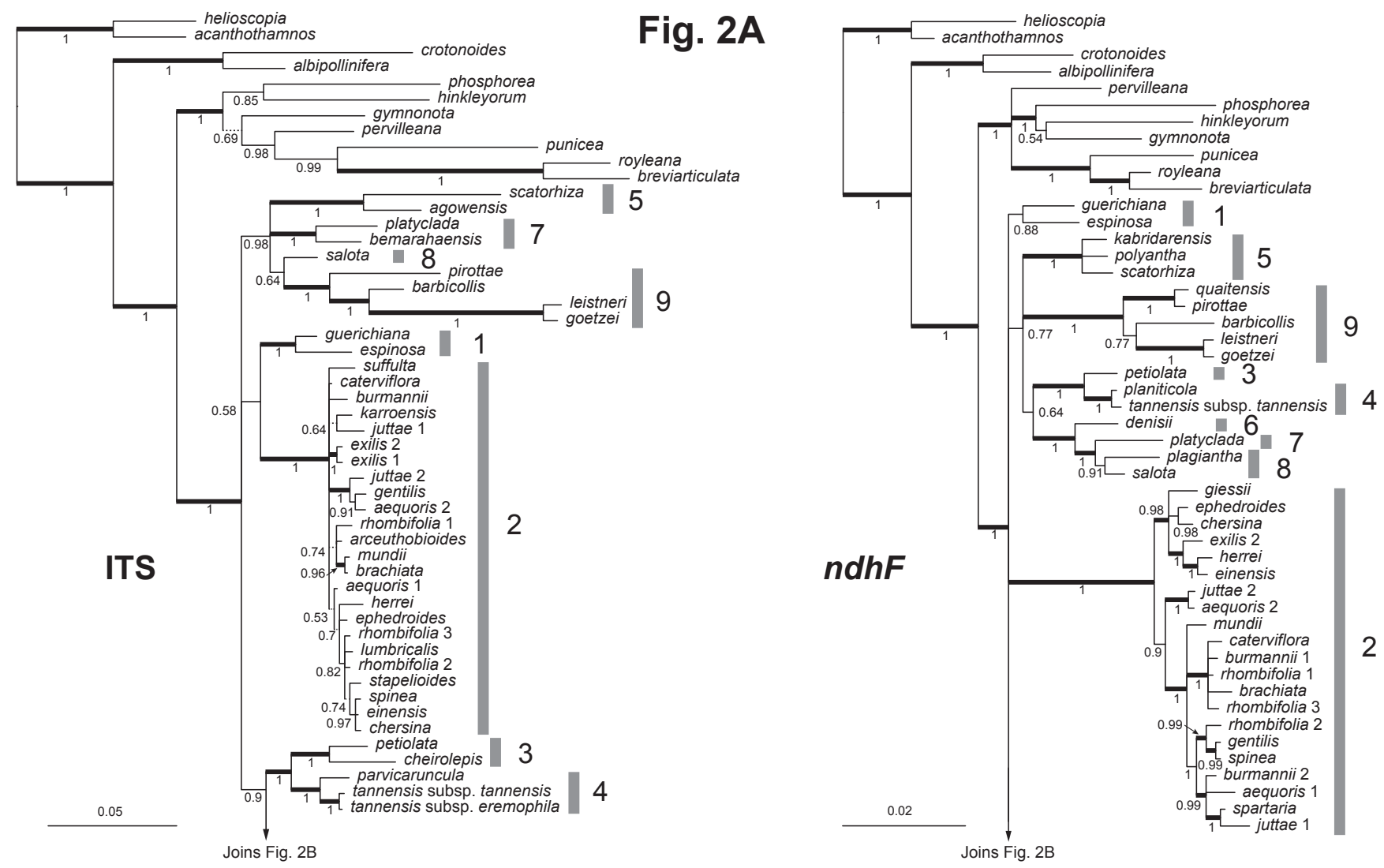

Fig. 2. Majority-rule consensus trees recovered from Bayesian analyses of the nuclear ITS and the chloroplast $n d h F$ coding regions. Numbers below the branches indicate Bayesian posterior probabilities (PP). Thick branches indicate maximum likelihood bootstrap percentages (MLB) $\geq 70$ and $\mathrm{PP} \geq 0.95$, and branches in dashed lines have $\mathrm{MLB}<50$ and $\mathrm{PP}<0.80$. Branch length scale on lower left of each tree. Numbers correspond to numbered sections in Fig. 3 and in the taxonomic treatment. $1=$ sect. Espinosae; $2=$ sect. Articulofruticosae; $3=$ sect. Cheirolepidium; $4=$ sect. Eremophyton; $5=$ sect. Scatorhizae $; 6=$ sect. Denisiae $;=$ sect. Bosseriae $; 8=$ sect. Plagianthae $; 9=$ sect. Frondosae $; 10=$ sect. Tenellae; $11=$ sect. Gueinziae $; 12=$ sect. Crossadenia $; 13=$ sect. Anisophyllum; $14=$ sect. Poinsettia $; 15=$ sect. Alectoroctonum. 
Joins Fig. 2A

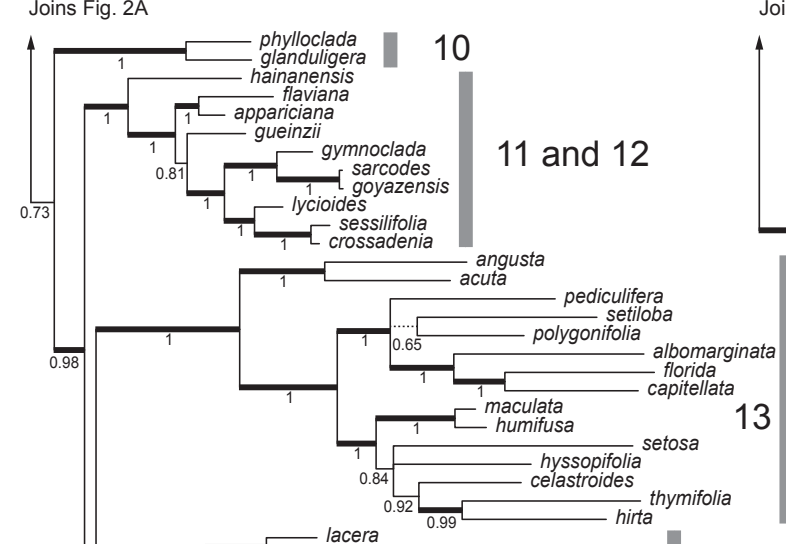

Fig. 2B

\section{.}
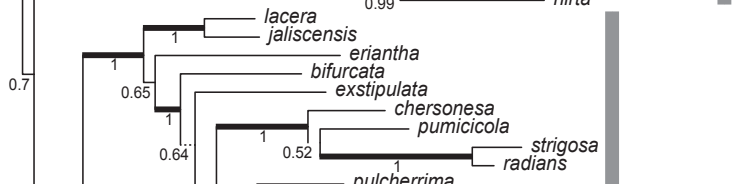

ins Fig. 2A

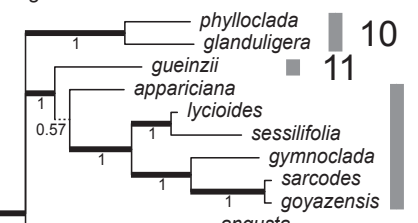

12

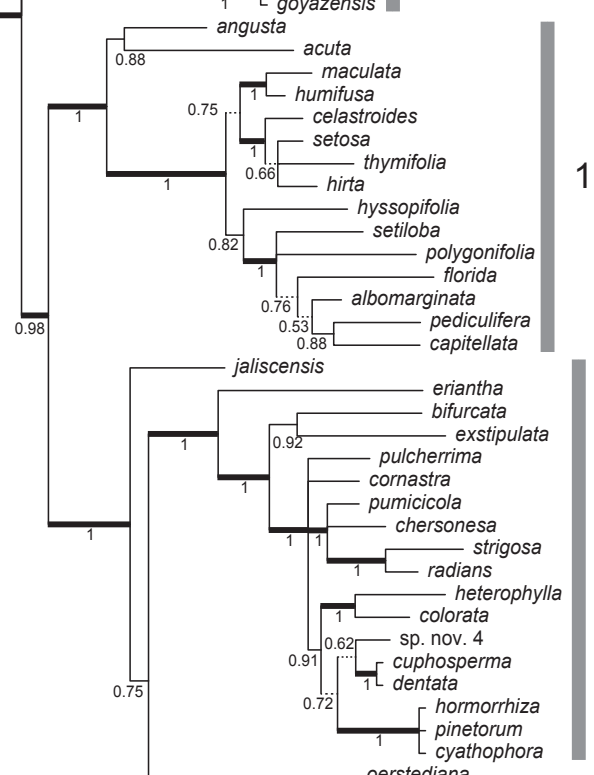

13

14
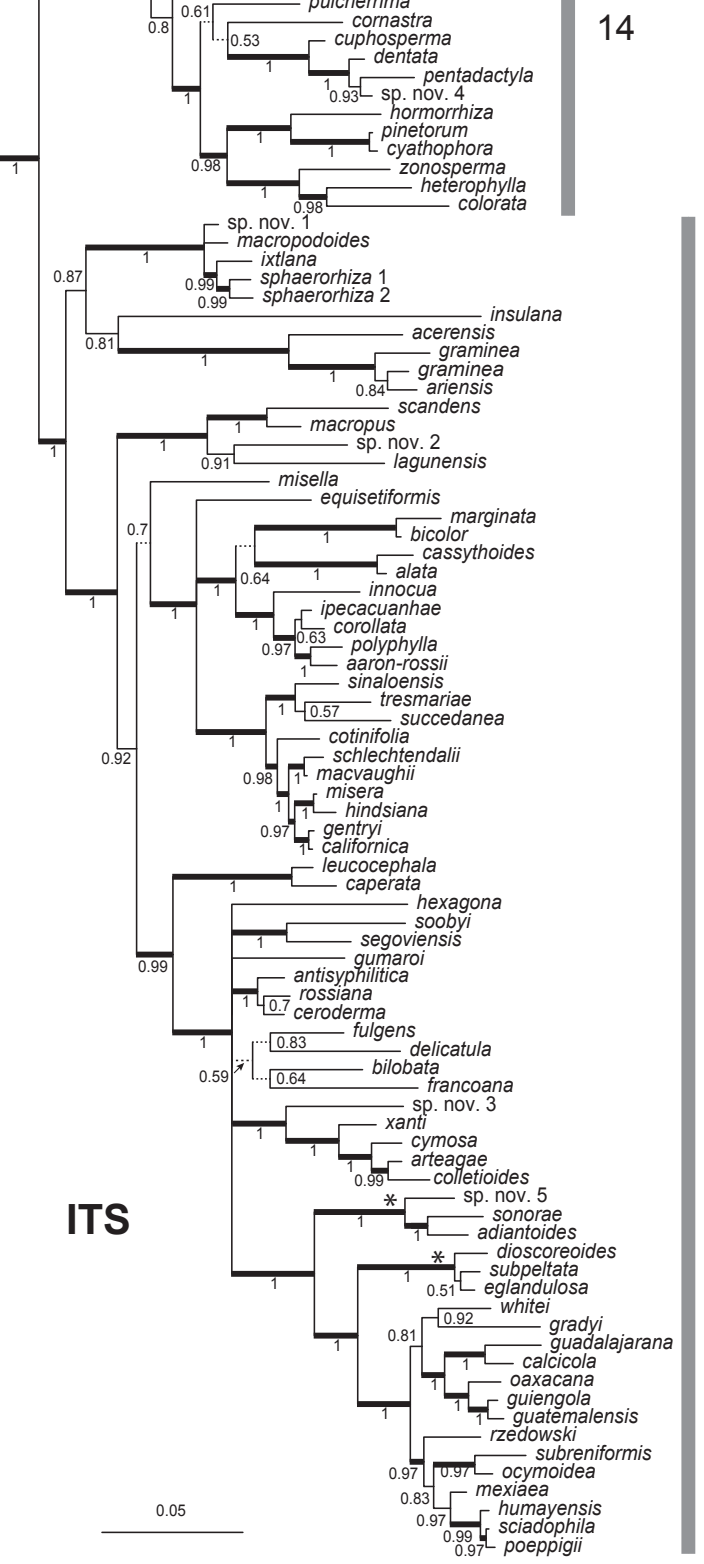

15

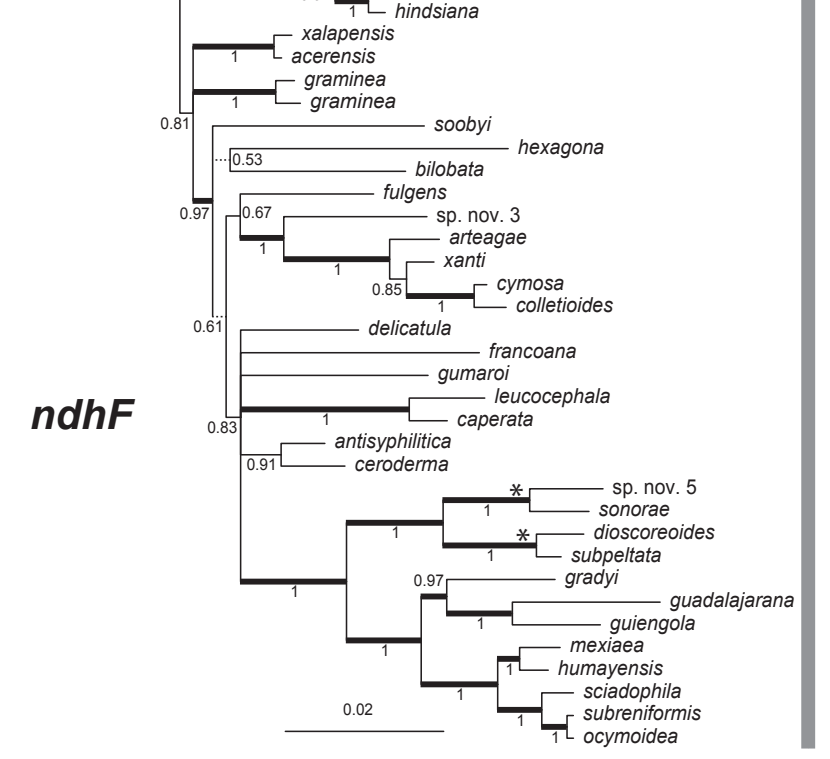


first one. In that case, we propose that their "sect. Chamaesyce" needs to be divided into six sections: sect. Tenellae, sect. Gueinziae, sect. Crossadenia, sect. Anisophyllum, sect. Poinsettia, and sect. Alectoroctonum. In addition, we designate six additional Old World sections to accommodate species that were either unsampled or unplaced by Bruyns \& al. (2006), namely, sect. Cheirolepidium, sect. Eremophyton, sect. Scatorhizae, sect. Denisiae, sect. Bosseriae, and sect. Plagianthae. In the following discussion, we focus on comparing our results to the marker-rich but relatively taxon-poor "backbone" analysis of Horn \& al. (2012a).

The Old World grade. - In Fig. 4, clades from sect. Espinosae up to sect. Tenellae are entirely Old World, forming the early diverging Old World grade in subg. Chamaesyce. Within this group, BI analysis of ITS places sect. Eremophyton + sect. Cheirolepidium as sister to the petaloid appendage clade, similar to the placement in Bruyns \& al. (2006), which was also based on BI of ITS alone (Fig. 2A). However, ML analysis of ITS, and both BI and ML analyses of $n d h F$, all support this clade as sister to the Madagascar clade. The cause of this incongruence between $\mathrm{BI}$ and $\mathrm{ML}$ is unknown, but it could be because BI is more prone to long-branch attraction (Kolaczkowski \& Thornton, 2009).

Our results conflict with those of Horn \& al. (2012a) as to the earliest branching event within the clade of subg. Chamaesyce (Fig. 4). Our combined analysis recovered sect.

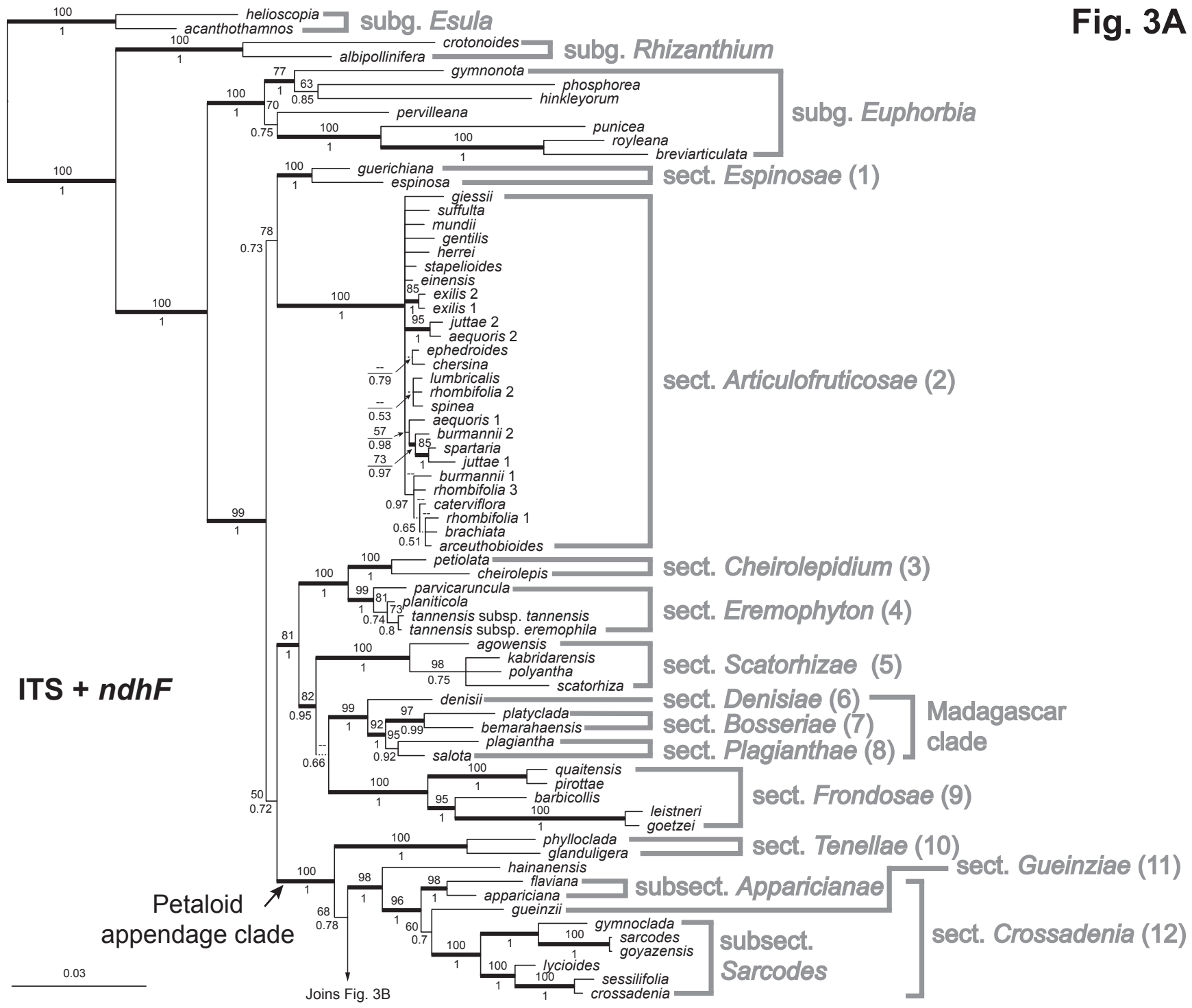

Fig. 3. Majority-rule consensus tree recovered from Bayesian analyses of the combined dataset (ITS $+n d h F$ ) with designated names of taxonomic units. Numbers above the branches indicate maximum likelihood bootstrap percentages (MLB), and numbers below the branches are Bayesian posterior probabilities (PP). Thick branches indicate MLB $\geq 70$ and $\mathrm{PP} \geq 0.95$, and branches in dashed lines have MLB $<50$ and PP $<0.80$. Branch length scale on lower left. Numbers next to each section correspond to numbers in Fig. 2 and in the taxonomic treatment. Subgroups within sect. Alectoroctonum are indicated with hyphenated numbers. 


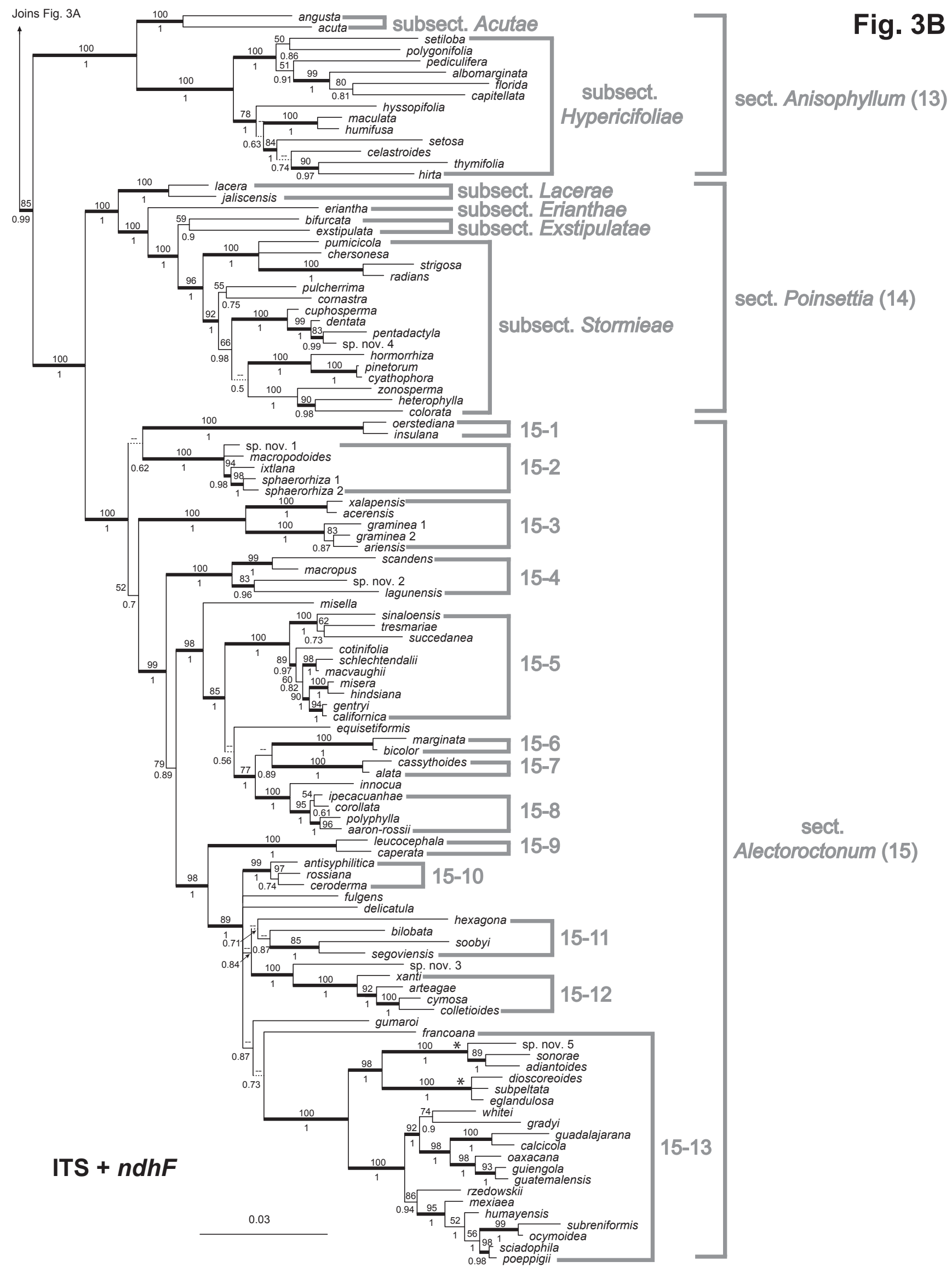


Articulofruticosae + sect. Espinosae as sister to the rest of the subgenus with moderate support. However, Horn \& al. (2012a) recovered sect. Cheirolepidium + sect. Eremophyton + sect. Scatorhizae + the Madagascar clade + sect. Frondosae as sister to the rest of subg. Chamaesyce. The latter received much stronger statistical support and may be more accurate because of their deeper molecular sampling.

Our results also disagree with Park \& Jansen's (2007) placement of $E$. cuneata. The E. cuneata sequence retrieved from GenBank (specimen/voucher Park 24023) was nested in our sect. Scatorhizae (not shown). However, our own fieldcollected sample of E. cuneata is placed within Euphorbia subg. Rhizanthium (Riina \& al., in prep.), as was another collection sequenced by Bruyns \& al. (2011). Park \& Jansen's (2007) E. cuneata has the same sequence as the E. polyantha $n d h F$ sequence by Steinmann \& Porter (2002), except that Park's $n d h F$ sequence has a 9-bp deletion in the middle. Because of this, we believe that Park \& Jansen (2007) misidentified E. polyantha as $E$. cuneata in their paper.

Among the ten sections we recognize in the Old World grade, sect. Tenellae is of particular interest because some of its members share petaloid gland appendages (though they are vestigial or absent in some species - see later descriptions) with the Old World-eastern Brazilian clade + the New World clade. Petaloid appendages (Fig. 1I-J) likely evolved in the common ancestor of sect. Tenellae+Old World-eastern Brazilian clade + the New World clade, and together they form the "petaloid appendage clade" (Fig. 4; Horn \& al., 2012a), which also corresponds to the "Agaloma alliance" of Steinmann \& Porter (2002).

The Old World-eastern Brazilian clade. - With substantially increased taxon sampling compared to all previous studies, our analyses recovered two Old World species, E. hainanensis Croizat and E. gueinzii Boiss., that group together with the Brazilian sect. Crossadenia rather than with any other Old World group (Figs. 2, 3). However, we still consider the position of E. hainanensis to be doubtful. It is a shrub endemic to Hainan Island of southern China, and it is distinctive in having three cyathial glands and has been postulated to be closely related to species from tropical Australasia that belong to Euphorbia subg. Euphorbia (Croizat, 1940; Dorsey \& al., subm.). This is a rare island endemic species, and we were only able to obtain a single ITS sequence. On the other hand, the placement of E. gueinzii is more reliable, with both ITS and $n d h F$ sequences placing it close to sect. Crossadenia. The phylogenetic placement of a separate accession of E. gueinzii, sequenced for ITS at the Smithsonian Institution, was congruent with our results (K.J. Wurdack, pers. comm.).

Although ITS data places E. gueinzii within sect. Crossadenia with moderate support, $n d h F$ data moderately supports its sister relationship to sect. Crossadenia. The combined analysis places it within sect. Crossadenia, but the support for this is weak. Because of its distinctive morphology and widely disjunct South African distribution compared to the otherwise entirely Brazilian sect. Crossadenia, the $n d h F$ placement is more likely to reflect the relationships of E. gueinzii. Consequently, we propose a new section for E. gueinzii, based on its position as sister to sect. Crossadenia in the $n d h F$ tree. In the case of the enigmatic $E$. hainanensis, we leave it unplaced until more data are available.

Given the pattern of distribution summarized in Fig. 4 and the postulated age of Euphorbia (36 Ma) that would exclude Gondwanan vicariance (Bruyns \& al., 2011), a possible biogeographic scenario is that New World groups in subg. Chamaesyce did not have a single origin from the Old World, but that sect. Crossadenia became established in Brazil first, and then there was a separate introduction accounting for the rest of the New World clade. Alternatively, there could have been a single long-distance dispersal from the Old World to the New World, followed by back-dispersal to the Old World. It is unclear which scenario is more likely until further information on E. gueinzii, E. hainanensis and their close relatives is available.

The (largely) New World clade. - Sister to the Old Worldeastern Brazilian clade is a largely New World clade of more than 500 species. This mainly New World clade consists of three major subclades [1(2,3)]: (1) Section Anisophyllum is distinctive in being mostly $\mathrm{C}_{4}$ and having a specialized growth form with early abortion of the main shoot. It is most prevalent in warm, semi-desert regions and disturbed areas worldwide, with its greatest diversity in the New World. (2) Section Poinsettia is characterized by reduction or loss of petaloid

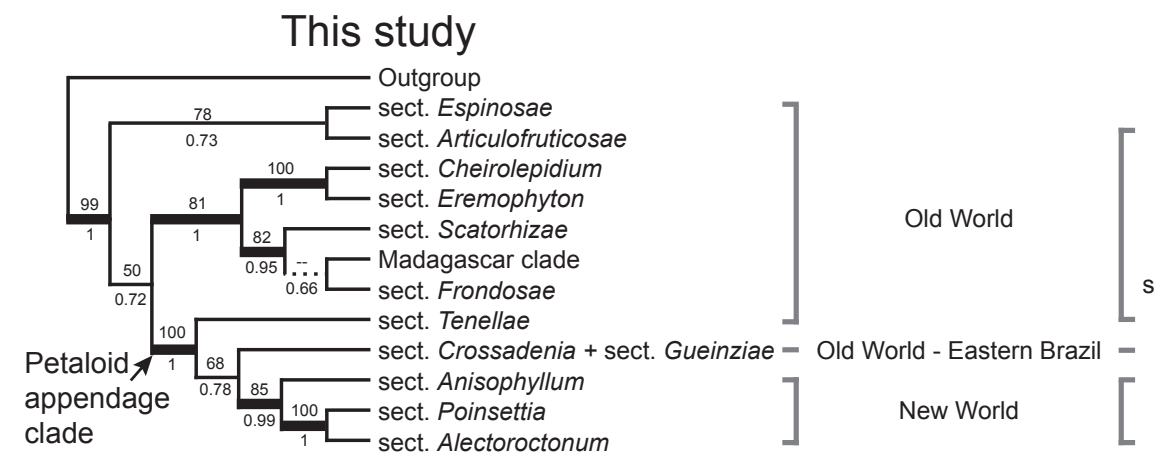

\section{Horn \& al., 2012a}

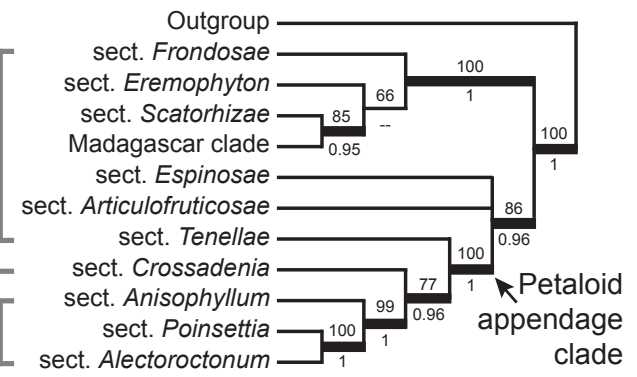

Fig. 4. Cladograms comparing major clades from this study and the "backbone" phylogeny (Horn \& al., 2012a). Numbers above the branches indicate maximum likelihood bootstrap percentages (MLB), and numbers below the branches are Bayesian posterior probabilities (PP). Thick branches indicate MLB $\geq 70$ and $\mathrm{PP} \geq 0.95$, and branches in dashed lines have MLB $<50$ and $\mathrm{PP}<0.80$. 
gland appendages and the development of brightly colored leafy bracts subtending congested terminal synflorescences, with the whole structure resembling a large blossom. It occurs mainly in forests and desert scrub of subtropical North America. (3) Section Alectoroctonum corresponds largely to the former subg. Agaloma (Raf.) House and is predominantly composed of herbs and shrubs, but also has some pencil-stem succulents with CAM photosynthesis. All species in this group have petaloid cyathial gland appendages, and sometimes they are quite showy. This group occurs in desert scrub to moist montane forests and prairies in subtropical to temperate areas throughout the Americas.

Within this New World clade there has been a considerable divergence of classification schemes. Bruyns \& al. (2006) opted to lump the entire "petaloid appendage clade" into a single section "Chamaesyce". On the other hand, within the New World clade alone, there are three well-supported clades, each or part of which have been treated previously at the rank of subgenus or even genus (e.g., "Chamaesyce", "Poinsettia", and "Agaloma"; see Dressler, 1961; Koutnik, 1984; Ward, 2001). If we were to follow this tendency and recognize genera or subgenera here, we would have to break up groups in the Old World grade into separate genera or subgenera as well in order to preserve monophyly. Instead, we choose to recognize three sections within the New World clade: sect. Poinsettia, sect. Anisophyllum, and sect. Alectoroctonum.

- Section Poinsettia. - In view of our molecular results and a re-evaluation of the morphological characters of the group, we propose a broader circumscription of sect. Poinsettia compared to the previous treatments by Dressler (1961) and Mayfield (1997). These authors restricted the application of the name "Poinsettia" to what we recognize here as subsect. Stormieae Croizat, namely those species with deeply cup-shaped involucral glands that lack petaloid appendages and are usually one or few in number (Fig. 1K). Other characteristic features commonly found in these species include colored bracts subtending the congested terminal cymes; pandurately lobed to linear, often heteromorphic leaves with at least some serration on the margins; glandular stipules; and coarsely tuberculate seeds, sometimes with a deeply sunken caruncular facet.

The three other subsections that we recognize in sect. Poinsettia are successively sister to subsect. Stormieae, beginning with subsect. Exstipulatae, followed by subsect. Erianthae, and then subsect. Lacerae (Fig. 3B). These three subsections all have some kind of involucral gland appendage, but that character is variable within the entire section, and two species nested in subsect. Stormieae, E. chersonesa and E. cornastra, have been reported to have a rudimentary appendage on the outer lip of the glands (Huft, 1984; Mayfield, 1997). In the case of E. bifurcata, which is placed here in subsect. Exstipulatae, it would be an otherwise indistinguishable member of subsect. Stormieae if not for the whitish appendage of its usually single cupular gland. Except for E. eriantha, which was placed by Boissier (1862) in sect. Poinsettia, the species in the three new subsections proposed here were previously included in sect. Zygophyllidium (Boissier, 1862; Dressler, 1961; Huft, 1984), which is included within sect. Alectoroctonum in our classification.
In addition to the molecular evidence, which strongly supports the monophyly of an expanded sect. Poinsettia (PP 1; MLB 100), there are morphological characters that support the inclusion of the additional species in sect. Poinsettia, and, conversely, their exclusion from sect. Alectoroctonum. First are the serrate leaf margins, which are evident in all species of sect. Poinsettia, except E. pinetorum, E. colorata, E. restiacea (all in subsect. Stormieae), and E. eriantha (subsect. Erianthae), although teeth can usually be seen in the latter two species under magnification. These four species all have linear leaves, and their teeth may have become inconspicuous or obsolete as the leaves became narrower. On the other hand, serrate leaves are very rare in sect. Alectoroctonum. Both species of subsect. Lacerae, which is sister to the other three subsections of sect. Poinsettia, have serrate, heteromorphic and/or pandurate leaves, which are usually considered to be hallmarks of sect. Poinsettia s.str. The feathery gland appendages of subsect. Erianthae (Fig. 1H) are unique in the genus and bear little resemblance to any of those in sect. Alectoroctonum. Likewise, the two-horned gland appendages in E. lacera are very different from the petaloid appendages in sect. Alectoroctonum.

Another factor that may have confounded the recognition of an expanded sect. Poinsettia distinct from sect. Alectoroctonum in the past was the erroneous placement of E. bilobata in sect. Poinsettia in the molecular phylogeny of Steinmann \& Porter (2002). Euphorbia bilobata is a true member of sect. Alectoroctonum, as shown by its placement in this study close to E. hexagona (the type species of Boissier's sect. Zygophyllidium; Fig. 3B); a review of its morphological features shows that they are fully consistent with its placement in sect. Alectoroctonum. Thus the position of E. bilobata in Steinmann \& Porter (2002) was likely due to an error.

In summary, we see no overriding morphological conflicts with sect. Alectoroctonum in expanding the circumscription of sect. Poinsettia to include the five additional species in three subsections recognized here. Within the context of the "petaloid appendage clade" (Horn \& al., 2012a) to which sect. Poinsettia belongs, it is not surprising that the earliest diverging subsections in section Poinsettia would have petaloid appendages and that these were subsequently lost in subsect. Stormieae.

- Section Anisophyllum. - Boissier (1862) proposed eight subdivisions within sect. Anisophyllum. Since then, due to the relatively homogenous morphology and wide distribution of this group, Boissier's classification scheme remained largely unchanged except for some minor modifications (Binojkumar \& Balakrishnan, 2010). Yang \& Berry's (2011) analyses of chloroplast markers strongly supported three major subclades within sect. Anisophyllum [1(2,3)]: (1) the Acuta clade, with only three species endemic to southwestern U.S.A. and northern Mexico that have $\mathrm{C}_{2}$ and $\mathrm{C}_{3}$ photosynthesis and glandular stipules; (2) the Peplis clade, consisting of mainly glabrous, perennial herbs with entire leaf margins that all have $\mathrm{C}_{4}$ photosynthesis and mostly endemic to the southwestern U.S.A. and northern Mexico; and (3) the Hypericifolia clade, consisting of annual and perennial herbs to woody perennials, often with toothed leaf margins and usually with some kind of pubescence, distributed worldwide, and which are also all $\mathrm{C}_{4}$. Since 
no character or character sets can readily distinguish species in the latter two clades, and nuclear markers indicate that there has been widespread reticulate evolution among members of these two clades, here we only recognize two subsections in subsect. Anisophyllum: the Acuta clade constituting subsect. Acutae, and all remaining species comprising subsect. Hypericifoliae.

- Section Alectoroctonum. - Classification within sect. Alectoroctonum is difficult due to its diversity of growth forms and the incompletely resolved phylogeny we obtained. Shrubs have evolved several times from herbaceous ancestors (Horn \& al., 2012a), and morphologically similar species repeatedly turn out to belong to distinct groups in our molecular phylogeny. In addition, the majority of the deep branches in the section are short and are poorly or only moderately supported (Fig. 3B), and some well-supported branches conflict among markers (Fig. 2B). Between our ITS and $n d h F$ results (Fig. 2B), the two clades marked with an asterisk are sister to each other in the $n d h F$ analysis but form a grade in the ITS analysis, with each placement being well-supported. Additional gene regions such as nuclear ribosomal ETS, chloroplast matK, and the nuclear low-copy coding region exon 9 of EMB2765 revealed even more extensive conflicts among well-supported clades (data not shown). Therefore, additional markers, expanded taxon sampling, and careful morphological studies are needed to better resolve relationships within sect. Alectoroctonum and to formally circumscribe subsections. Here we discuss informal species groups that are well supported by both morphological and molecular data, and then point out ambiguities that will require further investigation.

Clades 15-1 to 15-4 together form the basal grade of sect. Alectoroctonum (Fig. 3B). The majority of species in this grade occupy mid-elevation pine-oak forests in Mexico, while clade 15-1 and E. acerensis of clade 15-3 occur in the Caribbean and South America. Euphorbia graminea, also part of clade 15-3, is a widespread and variable species across warm regions of North and South America. Species in clade 15-1 are distinctive in having only two glands per cyathium (sometimes three in E. insulana). Clade 15-2 is endemic to Mexico and has distinctive globose-tuberous roots (Huft, 1979). However, E. macropus, which is another Mexican species with globose roots, is placed in clade 15-4 in our analysis, and it indeed shares morphological characters with both clade 15-2 and 15-4. Clade 15-3 is distinctive in having stalked glands and four or five glands per cyathium (sometimes also two or three in E. graminea); leaf shape is highly variable, and leaf margins are sometimes sinuate, instead of being entire as in most of sect. Alectoroctonum. Both E. graminea and E. ariensis share white, showy bracts. Euphorbia graminea is very similar to both species of clade 15-1 in gross morphology, but it differs from them in having glabrous instead of densely pubescent capsules (Ward, 2001). Euphorbia graminea is the type of sect. Cyttarospermum Boiss., but other species that were placed in that section by Boissier (1862) are spread over many separate clades within sect. Alectoroctonum. Species in clade 15-4 are characterized by opposite leaves and branches, four or five glands per cyathium, green gland appendages, and all are confined to Mexico.
Euphorbia misella appears in an isolated position, sister to clades $15-5$ to $15-8$ (Fig. 3B). It is a tiny fall annual herb native to high elevation pine-oak forests in Mexico. It is very similar to E. sinaloensis and E. succedanea of clade 15-5 in morphology, growth form, habitat and distribution. However, these three Mexican annuals do not form a monophyletic group in our analysis. Clade 15-5 contains mostly shrubs. Species from E. misera to E. californica have alternate branches and spirally arranged leaves on short shoots, and they all occur in desert scrub of the Sonoran Desert. In contrast, species from E. cotinifolia to E. macvaughii have verticillate leaves and branches and occupy tropical forests from Mexico to South America. Clade 15-6 corresponds to subsect. Petaloma Raf. ex Pax; both E. marginata and E. bicolor are annual herbs that are widely cultivated as ornamentals for their showy, white-margined bracts. Clade 15-7 corresponds to sect. Arthrothamnus subsect. (noted as " $§$ " in Boissier, 1862) Americanae Boiss., and is characterized by dioecious pencil-stem shrubs, with opposite or whorled, ridged branches; the leaves are scale-like or caducous, and they lack stipules. Both E. alata and E. cassythoides occur in the Greater Antilles (Cuba and Jamaica, respectively). The closely related Galápagos endemic E. equisetiformis is also a leafless opposite-stemmed shrub, yet these three species do not form a monophyletic group in our analyses. Euphorbia innocua occurs in an isolated position sister to clade 15-8; it is a prostrate herb with four glands that superficially resembles sect. Anisophyllum; it was treated by Webster (1967) as the sole representative of sect. Tithymalopsis subsect. Innocuae G.L. Webster. Webster (1967) considered it to be intermediate between sect. Alectoroctonum and sect. Anisophyllum, but such a relationship is not supported by our analyses. Clade 15-8 largely corresponds to sect. Tithymalopsis subsect. Ipecacuanhae Boiss. (Huft, 1979; Holmgren \& Holmgren, 1988). It represents the northernmost distribution for sect. Alectoroctonum, extending from the eastern United States north to southern Canada. Species in this group are perennial herbs with leaves that are rounded at the apex and with ovoid seeds that are rounded in cross-section, smooth or shallowly pitted on the surface, and lacking a caruncle (Huft, 1979).

Both species in clade 15-9, E. leucocephala and E. caperata, are shrubs with verticillate leaves and five involucral glands (Fig. 3B). They differ from other shrubs of sect. Alectoroctonum in having showy, entirely white bracts. Both species have carunculate seeds, which is otherwise rare in sect. Alectoroctonum. Clade 15-10 includes three species that are densely branched pencil-stem shrubs with a waxy surface, with cyathia in axillary cymes, five involucral glands with well-developed appendages, and seeds that are ovoid with a smooth surface. Between clades 15-10 and 15-11, there are two species that form part of a polytomy and whose exact affinities are unclear. One of these, E. fulgens ("scarlet plume"), is cultivated for its large and showy gland appendages. In the weakly supported clade 15-11, E. bilobata and E. hexagona both have only opposite leaves and branches and were formerly treated as part of sect. Zygophyllidium Boiss. The remaining species of sect. Zygophyllidium as defined by Boissier (1862) are scattered in other parts of sect. Alectoroctonum 
and in sect. Poinsettia in our analyses. The other two species of clade 15-11, E. soobyi and E. segoviensis, are morphologically consistent with clade 15-13 and may prove to belong to that clade with additional data. Clade 15-12 includes shrubs with verticillate leaves and branches, deciduous leaves, and cyathia that are clustered in dense cymes and have five or six cyathial glands. Between clades 15-12 and 15-13, E. gumaroi is a small succulent, decumbent species that was compared to E. antisyphilitica in its original description (Meyrán García, 2000), but such an affinity is not supported by our molecular data. Cyathia in E. gumaroi are single and terminal rather than in axillary cymes as in E. antisyphilitica. Finally, clade 15-13 is a group of about 25 species of herbs and shrubs from warm parts of North and South America. Some species in this clade were treated as part of sect. Cyttarospermum Boiss. (Boissier, 1862), but the type of that section (E. graminea) belongs in clade 15-3. Species in clade 15-13 are characterized by having petioles that are longer than the leaf blades, five cyathial glands, often deeply lobed gland appendages, and ecarunculate seeds that are deeply pitted, with protrusions on distinctive honeycombed ridges (Fig. 1Q).

Evolution of growth forms and photosynthetic types. - The basic structure of a Euphorbia plant is shown in Fig. $5 \mathrm{~A}$. Annual members of the genus best exemplify this architecture, as various parts of the plant may die back in perennials. Distal to the cotyledonary node, the plant sometimes develops nodes with opposite leaves and side branches. Further up the main shoot, both leaves and branches switch to being alternate. Either, neither, or both of the opposite/alternate vegetative sections can be absent. Later, the main shoot terminates with a whorl of leaves and usually an equal number of branches, concomitant with a switch to reproductive growth, which is typically a pleiochasium of cymes. In this scheme, the synflorescence in Euphorbia typically has three levels of organization
(Fig. 5A): (1) the cyathium itself bearing tightly packed male and/or female flowers, (2) the cyathia arranged in cymes, and (3) the cymes arranged in pleiochasia at the point of apical termination of the main stem. Despite various terminologies that have been applied to these three organization levels, here we call the leaves (or bracts when they are not green) that directly subtend a single cyathium "subcyathial bracts", leaves/bracts at lower nodes of the synflorescence "dichasial bracts", and the lowest whorl of leaves associated with the synflorescence "pleiochasial bracts" (Fig. 5A; Molero \& Rovira, 1992).

One notable modification of the basic plant structure in Euphorbia is the lack of apical growth of the main shoot (Figs. 1E, 5B; Hayden, 1988). This growth form is a synapomorphy for sect. Anisophyllum, in which essentially the entire plant body resembles a synflorescence. Together with juvenile flowering, copious seed production, and $\mathrm{C}_{4}$ photosynthesis, sect. Anisophyllum has been very successful in colonizing warm and semi-desert areas and disturbed habitats worldwide. However, both E. remyi and E. halemanui, two ascending shrubs endemic to the Hawaiian Archipelago, develop main shoots with continued apical growth and opposite leaves (Koutnik, 1987). In E. potentilloides, and occasionally in E. angusta and $E$. viscoides, the annual growth terminates in a whorl of three or more leaves before producing the terminal synflorescence (Simmons \& Hayden, 1997).

Another notable example of modification in growth form is the continued elongation of main shoots with alternate or verticillate leaves and branches (Fig. 5C). In this growth form, cyathial cymes are axillary instead of arranged in a terminal whorl. This type is seen in all members of clades 15-12 and most of 15-13 of sect. Alectoroctonum (Figs. 1C). A further modification of this growth form occurs when stems become fleshy and photosynthetic, and leaves are deciduous or reduced; then the plants become stem succulents with alternate

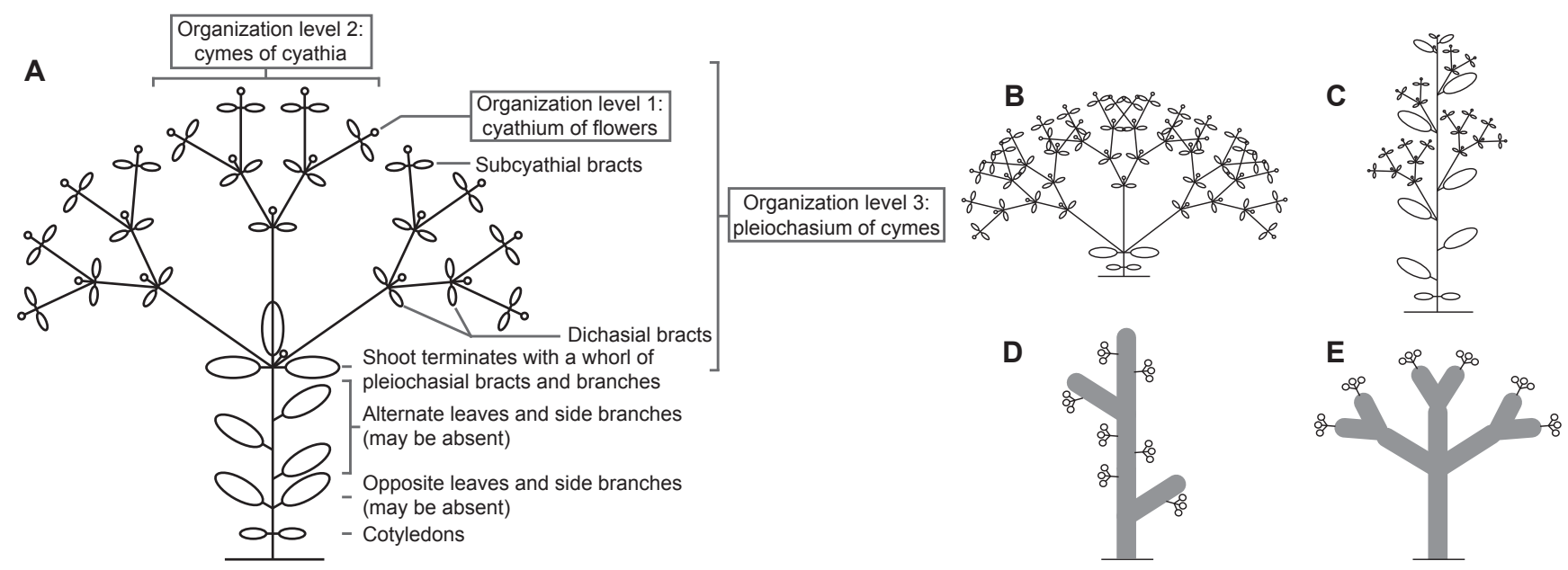

Fig. 5. Diversity of growth forms in Euphorbia subg. Chamaesyce. A, The basic growth form variations in Euphorbia, with the three synflorescence organization levels (Wheeler, 1941: pl. 655; Molero \& Rovira, 1992). B-E, Modifications of the basic growth form: B, early termination of the main shoot; C, main shoot indeterminate and cymes axillary; D, similar to C but stems become succulent; and $\mathbf{E}$, stem succulents with terminal cymes. 
branching and axillary cyathia or cyathial cymes (Figs. 5D). This type of growth form is seen in sect. Plagianthae (E. plagiantha, Fig. 1A) and sect. Alectoroctonum (all members of clade 15-10, and E. gradyi of clade 15-13).

A second type of stem succulence of separate origin occurs when the main shoot terminates with a pleiochasial cyme, and both the vegetative section and the synflorescence (except for the cyathia themselves) become succulent. This way the plants have mostly dichotomous or whorled branching, with terminal cyathia or cyathial cymes (Fig. 5E). This growth form is found in all species of sect. Articulofruticosae (Fig. 1B), sect. Bosseriae, part of sect. Crossadenia (subsect. Apparicianae+ E. gymnoclada), and part of sect. Alectoroctonum (clade 15-7 + E. equisetiformis). Perhaps a third type of succulent growth form is evident in Euphorbia gumaroi, which is a Mexican member of sect. Alectoroctonum that is unique in having alternate succulent branches with single, terminal cyathia (Fig. 1D; Meyrán García, 2000).

Euphorbia is extremely diverse in succulent growth forms, and most of the diversity in succulence is found in subg. Euphorbia and subg. Rhizanthium. Still, in subg. Chamaesyce, stem succulence has evolved at least six times, with multiple origins in both the Old World (southern Africa, Madagascar) and the New World (eastern Brazil, North America). Occurrences of stem succulence are usually associated with CAM photosynthesis. Stable isotope ratios $(\delta 13 \mathrm{C})$ have been tested in sect. Articulofruticosae, within which both E. ephedroides and $E$. rhombifolia have values typical of CAM plants. In sect. Bosseriae, E. platyclada was tested for $\delta 13 \mathrm{C}$ and has a typical CAM value; in sect. Crossadenia, E. appariciana has a ratio consistent with weak or facultative CAM expression; and in sect. Alectoroctonum, E. ceroderma (clade 15-10) has a value consistent with CAM photosynthesis (Horn \& al., 2012b).

Conclusions. - Euphorbia subg. Chamaesyce has been recircumscribed here based on molecular data. With taxon sampling covering nearly half of the ingroup species and a well-resolved phylogeny, we can now begin to understand evolutionary trends in a worldwide lineage with diverse growth forms and photosynthetic types. In the following treatment, we circumscribe fifteen sections that are each morphologically and geographically distinctive. This updated sectional and subsectional classification of subg. Chamaesyce includes descriptions and lists of accepted species for each section or subsection.

\section{- TAXONOMIC TREATMENT}

Species with molecular sequence data available in GenBank, either published here or previously, are shown in bold in the "Included species" lists under each section or subsection. A searchable and downloadable list of accepted names, their synonymies, type information and distribution for Euphorbia is available online at http://app.tolkin.org/projects/72/taxa (Riina \& Berry, 2012).

Euphorbia subg. Chamaesyce Raf. in Amer. Monthly Mag. \& Crit. Rev. 2: 119. 1817 - Lectotype: E. supina Raf.
(=E. maculata L.), designated by Wheeler in Contr. Gray Herb. 127: 59. 1939.

Rafinesque did not include E. chamaesyce L. in his circumscription of the subgenus, therefore Art. 22.6 of the ICBN does not apply here.

Annual or perennial herbs, shrubs or trees; rarely geophytes. Stems and leaves sometimes more or less fleshy to succulent, but not cactus-like. Taproot slender or variously thickened, cylindrical to globose. Branches few to many, prostrate, decumbent, or upright; alternate, opposite and/or ternate; sometimes the apices become spine-like. Leaves alternate, opposite and/or ternate, glabrous or variously pubescent, sometimes dark green veins visible on species with $\mathrm{C}_{4}$ photosynthesis; stipules glandular, linear, subulate, triangular, or inconspicuous. Cyathia bisexual, rarely unisexual, solitary or in cymes, axillary or terminal, sometimes subtended by green or brightly colored bracts, actinomorphic or slightly zygomorphic; glands (1-)4-5(-7), often with petaloid appendages, less often appendages horn-like, linear, or missing; ovary glabrous or pubescent; styles 3, connate or free at the base, bifid or entire. Capsules 3-lobed or less often subglobose. Seeds ovoid or oblong, 4-angled, less often 3-angled or rounded in crosssection; surface variously sculptured or smooth, carunculate or ecarunculate.

Discussion. - Within Euphorbia subg. Chamaesyce, a total of 566-574 (see discussion for sect. Articulofruticosae) species are recognized and distributed among 15 sections, with E. hainanensis Croizat sampled but left unplaced as to section. There are another 20 or so species in the process of being formally described, and there are still some unplaced species in Euphorbia that may prove to belong to this subgenus with further study.

Due to the high level of homoplasy of morphological character states in Euphorbia (Horn \& al., 2012a), a key to the sections of subg. Chamaesyce that is of practical value needs to begin with the entire genus, in which sections can be keyed out directly instead of keying to the subgenera first. Since the taxonomic revisions for the other three subgenera are in different stages of completion, it would be premature to attempt such a key at this point.

1. Euphorbia sect. Espinosae Pax \& K. Hoffm. in Engler, Veg. Erde 9 [Pflanzenw. Afrikas] 3, 2: 149. $1921 \equiv$ Euphorbia subsect. Espinosae (Pax \& K. Hoffm.) Pax \& K. Hoffm. in Engler \& Prantl, Nat. Pflanzenfam., ed. 2, 19c: 213. 1931 - Type: E. espinosa Pax.

Shrubs to small trees, stems with a shiny or papery bark, the stem apices often drying and becoming spine-like. Leaves alternate, shortly petiolate; stipules glandular, conspicuous. Cyathia bisexual, solitary, axillary, subsessile, or on lateral short shoots, surrounded at the base by a cluster of small leaflike or scarious bracts; glands 5, entire, yellow-green, exappendiculate (Fig. 1F); ovary subtended by a 3-lobed perianth; styles joined at the base, with spreading, bifid apices. Capsules well-exserted on a reflexed pedicel, deeply 3-lobed, glabrous. Seeds ovoid, slightly dorsiventrally compressed, smooth, with a cap-like caruncle. 
Distribution and habitat. - Southern and eastern Africa (Angola, Botswana, Namibia, northern South Africa, Kenya, Malawi, Tanzania, Zambia, Zimbabwe); hilly, deciduous woodlands, 300-1400 m.

Included species (2). - E. espinosa Pax and E. guerichiana Pax.

Discussion. - There are several other sections that resemble sect. Espinosae in their shrubby habit, coppery bark, and sometimes spinose branches. These include E. sect. Somalica S. Carter, E. sect. Lyciopsis Boiss., the E. balsamifera group (all in subg. Rhizanthium, also from Africa); and E. sect. Plagianthae (subg. Chamaesyce, from Madagascar).

2. Euphorbia sect. Articulofruticosae Bruyns in Taxon 55: 416. 2006 - Type: E. aequoris N.E. Br.

Generally dioecious, semi-woody to succulent shrubs; branches dichotomous or opposite, usually much-branched from the base; branches cylindrical or variously ridged, apices drying spine-like in some species. Leaves opposite, small and often scale-like, quickly deciduous leaving a calloused scar; stipules apparently absent or glandular and conspicuous. Cyathia or cyathial cymes terminal (sometimes appearing to be axillary when borne on apex of short shoots); cymes branching few to many times, internodes progressively shorter above; subcyathial bracts and dichasial bracts spathulate or similar to the leaves, deciduous. Cyathia small, usually unisexual, subsessile; glands 5, entire, exappendiculate; styles connate at the base and free above, bifid at the tip. Capsules subsessile or exserted and recurved, glabrous or pubescent. Seeds conical, obtusely 4-angled, surface finely tuberculate, ecarunculate (Fig. 10).

Distribution and habitat. - Most diverse in the arid winterrainfall region of western South Africa and southern Namibia, extending into southern Angola and Botswana and east to KwaZulu-Natal, South Africa. Growing in sandy soils or on rock outcrops, in low shrublands to deserts and consolidated dunes, from sea level to ca. $2000 \mathrm{~m}$.

Included species (18-26). - E. aequoris N.E. Br. [=E. juttae sensu Bruyns], E. angrae N.E. Br., E. arceuthobioides Boiss. [= E. tenax sensu Bruyns], E. brachiata E. Mey. ex Boiss. [=E. rhombifolia sensu Bruyns], E. burmannii E. Mey. ex Boiss., E. caterviflora N.E. Br. [= E. rhombifolia sensu Bruyns], E. chersina N.E. Br. [=E. rhombifolia sensu Bruyns], E. einensis G. Will. [= E. angrae sensu Bruyns], E. ephedroides E. Mey. ex Boiss., E. exilis L.C. Leach, E. gentilis N.E. Br., E. giessii L.C. Leach, E. herrei A.C. White, R.A. Dyer \& B. Sloane, E. juttae Dinter, E. lavranii L.C. Leach, E. lumbricalis L.C. Leach [=E. stapelioides sensu Bruyns], E. mundii N.E. Br. [=E. rhombifolia sensu Bruyns], E. muricata Thunb., E. negromontana N.E. Br., E. rhombifolia Boiss., E. spartaria N.E. Br., E. spinea N.E. Br., E. stapelioides Boiss., E. suffulta Bruyns, E. tenax Burch., E. verruculosa N.E. Br.

Discussion. - This is a very well characterized group of pencil-stemmed succulents with greatly reduced and caducous leaves, and they are readily distinguished by their opposite or dichotomous branching and mostly unisexual cyathia (Fig. 1B). However, species limits in this section are unclear, and the group is in need of a taxonomic revision. Bruyns \& al. (2011) and Bruyns (in press) recognized only 18 species in this section, but we are tentatively including here a number of names that are treated as synonyms in those publications. According to the age estimates of Bruyns \& al. (2011), this section diversified in southern Africa during the past $12 \mathrm{Ma}$.

3. Euphorbia sect. Cheirolepidium Boiss. in Candolle, Prodr. 15(2): 9, 70. 1862 E Euphorbia subsect. Cheirolepidium (Boiss.) Pax \& K. Hoffm. in Engler, Nat. Pflanzenfam., ed. 2, 19c: 213. $1931 \equiv$ Cystidospermum Prokh., Consp. Syst. Tithymalus Asiae Mediae: 25. 1933 E Euphorbia subg. Cystidospermum (Prokh.) Prokh. in Komarov \& al., Flora U.R.S.S. 14: 480. 1949 - Type: E. cheirolepis Fisch. \& C.A. Mey.

= Dematra Raf., Autik. Bot.: 96. 1840 E Euphorbia sect. Dematra (Raf.) Prokh. in Komarov \& al., Flora U.R.S.S. 14: 476. 1949 - Type: D. sericea Raf. (=E. petiolata Banks \& Sol.). = Euphorbia subsect. Crotonopsideae Boiss. in Candolle, Prodr. 15(2): 101. 1862 - Type: E. petiolata Banks \& Sol.

$=$ Ctenadenia Prokh., Consp. Syst. Tithymalus Asiae Mediae: 28. 1933 - Type: C. lanata (Sieb.) Prokh. (= E. petiolata Banks \& Sol.).

Annual erect herbs, well branched. Leaves and branches opposite at the base, alternate in the mid-section before the termination of apical growth and switch to dichotomous branching, with each fork subtended by dichasial bracts; leaves linear-lanceolate to elliptic or ovate, densely villous to subglabrous, margin distinctively spinulose-dentate; stipules subulate. Cyathia solitary between the forks of dichotomous branches, or few-clustered in axillary cymes; both dichasial and subcyathial bracts leaf-like but much reduced in size; glands 4 per cyathium, with deep finger-like to linear lobes, stalked (E. cheirolepis) or not (E. petiolata), yellow-green, sometimes turning red with age; styles 3 , free or connate at the base, tip entire; ovary densely pubescent, 3-lobed. Capsule exserted, pubescent. Seeds 4-angled, surface tuberculate; caruncle large and stipitate in E. petiolata (Fig. 1M), or distinctively ligulate with two long flaps in E. cheirolepis (Fig. 1N).

Distribution and habitat. - From northern Africa through Central Asia; fallow fields and dry, open habitats, 500-1500 m.

Included species (2). - E. cheirolepis Fisch. \& C.A. Mey., E. petiolata Banks \& Sol.

Discussion. - These two species have been variously treated as members of subg. Esula, and they are indeed anomalous geographically among the remaining groups of subg. Chamaesyce (excluding sect. Anisophyllum). However, the presence of stipules and the pectinate cyathial glands distinguish both species from members of subg. Esula. The ligulate caruncle in E. cheirolepis is unique in Euphorbia (Fig. 1N, Pahlevani \& Akhani, 2011). However, it is caducous, and seeds may appear to be ecarunculate on herbarium sheets.

The pectinate protrusions appear to extend directly from the rim of the glands (Fig. 1G), unlike the petaloid appendages in the "petaloid appendage clade", which appear to extend from the involucre and emerge from below the glands (Fig. 1I, J). 
4. Euphorbia sect. Eremophyton Boiss. in Candolle, Prodr. 15(2): 9, 70. $1862 \equiv$ Euphorbia subg. Eremophyton (Boiss.) L.C. Wheeler in Amer. Midland Naturalist 30: 483. $1943 \equiv$ Euphorbia subsect. Eueremophyton (Boiss.) Pax in Engler \& Prantl, Nat. Pflanzenfam. 3(5): 107. 1891 E Euphorbia sect. Eremophila Benth. \& F. Mueller, Fl. Austral. 6: 45. 1873, nom. illeg. (Art. 52.1) - Lectotype: E. eremophila A. Cunn. (三E. tannensis subsp. eremophila (A. Cunn.) D.C. Hassall), designated by Wheeler in Amer. Midland Naturalist 30: 483. 1943.

Annual or perennial herbs to small shrubs, glabrous to sparsely pubescent. Stems erect, multibranched; leaves and branches opposite at the base, alternate in the mid-section before the termination of apical growth and then switching to dichotomous branching, with each fork subtended by dichasial bracts. Leaves linear-lanceolate to ovate, margins serrate; stipules glandular or subulate. Cyathia solitary between the forks of dichotomous branches or few-clustered in axillary cymes, with dichasial and subcyathial bracts leaf-like but much reduced in size; glands 4, yellow, ovate, margins entire (exappendiculate) or crenate to palmatifid, ovary glabrous; styles 3 , connate at the base, bifid at the tips. Capsules exserted, erect, 3-lobed. Seeds more or less 4-angled, surface tuberculate to reticulate; caruncle present, variously shaped.

Distribution and habitat. - Australia, New Caledonia, Vanuatu; coastal sands to inland desert and scrub, sea level to $600 \mathrm{~m}$.

Included species (3). - E. parvicaruncula D.C. Hassall, E. planiticola D.C. Hassall, E. tannensis Spreng.

Discussion. - Boissier (1862) first established sect. Eremophyton to include three Old World species, but they now belong to three different sections in subg. Chamaescyce. Besides the lectotype of this section, E. eremophila A. Cunn., the African E. agowensis is placed by our analyses in sect. Scatorhizae, while the third species, the South African E. gueinzii, is placed in sect. Gueinziae. Wheeler (1943) broadened the concept of sect. Eremophyton and elevated it to the rank of subgenus, but this was a very heterogeneous assemblage of species that is not supported by molecular data.

Hassall (1977) treated five native Australian Euphorbia species as forming a natural group within Euphorbia subg. Eremophyton. However, our molecular data strongly reject the monophyly of all five species: E. stevenii and E. boophthona are both nested in E. subg. Euphorbia (Dorsey \& al., subm.), whereas the other three form a monophyletic group in subg. Chamaesyce, as treated here in a more restricted sect. Eremophyton. The placement of E. boophthona in subg. Chamaesyce by Zimmermann \& al. (2010) was most likely an error.

5. Euphorbia sect. Scatorhizae Y. Yang \& P.E. Berry, sect. nov. - Type: E. scatorhiza S. Carter.

Annual or perennial herbs, or shrubs; when woody often with peeling bark; with or without tubers. Leaves alternate basally, opposite distally, petiolate, margin entire or undulate, sometimes with gland-tipped marginal teeth at the base; stipules glandular or subulate. Cymes in 2-3-branched umbels or cyathia solitary; subcyathial bracts small to well-developed.
Cyathia sessile or subsessile, glands 4 or 5, elliptic to subcircular, exappendiculate; styles connate at the base, bifid at the tip. Ovary and capsule sessile or exserted on a recurved pedicel, 3-lobed, glabrous or pubescent. Seeds ovoid to oblong, more or less 4-angled in cross-section, dorsal-ventrally flattened, face smooth, wrinkled, or tuberculate; ecarunculate (E. kabridarensis) or with a large cap-like caruncle (E. applanata, E. agowensis, E. polyantha, E. scatorhiza, E. trichiocyma).

Distribution and habitat. - Africa (Angola, Ethiopia, Kenya, Somalia, Tanzania), Arabia (Saudi Arabia, Yemen), India; rocky or sandy scrub or deserts, 200-1850 m.

Included species (7). - E. agowensis Hochst. ex Boiss., E. kabridarensis Thulin, E. polyantha Pax, E. scatorhiza S. Carter, E. trichiocyma S. Carter. Species that may also belong here: E. applanata Thulin \& Gifri, E. suborbicularis Thulin.

Discussion. - Section Scatorhizae is characterized by non-succulent herbs to shrubs, sessile or subsessile cyathia, and flattened, 4-angled seeds. All five carunculate members have been treated in Euphorbia subg. Eremophyton (Boiss.) L.C. Wheeler (Carter \& Radcliffe-Smith, 1988; Thulin \& AlGifri, 1995), while the ecarunculate E. kabridarensis has been treated in sect. Lyciopsis Boiss. (Carter, 1992).

6. Euphorbia sect. Denisiae T. Haevermans \& X. Aubriot, sect. nov. - Type: E. denisii Oudejans.

Nonsucculent, low, densely branched dwarf shrubs to small trees, with rhizomes. Branches numerous, alternate, brownish green with transverse linear darker patches, twigs slightly succulent to ligneous. Leaves arranged spirally on short shoots, deciduous; blade obcordate to rounded, subpeltate with a cylindrical petiole, margin entire; stipules small, deciduous. Cyathia subsessile, bisexual, subterminal, subcyathial bracts present but extremely reduced, pubescent; glands 5, yellow-green, broadly ovate (E. denisii) or erect with the upper margin reclined (E. subpeltatophylla), exappendiculate; styles connate at base, bifid at the tip; ovary and capsule subsessile, erect, emerging from the cyathium at maturity; 3-lobed, surface smooth and glabrous. Seeds ovoid, more or less 4-angled, apex acute, surface smooth, with a small, reniform caruncle.

Distribution and habitat. - Southern Madagascar, in xerophytic vegetation, sea level to $200 \mathrm{~m}$.

Included species (2). - E. denisii Oudejans, E. subpeltatophylla Rauh.

Discussion. - Species from southern Madagascar in the E. tetraptera clade of subg. Euphorbia superficially resemble $E$. denisii and have been incorrectly identified as this species (Haevermans, 2003: 137, 166).

7. Euphorbia sect. Bosseriae T. Haevermans \& X. Aubriot, sect. nov. - Type: E. bosseri Leandri.

Perennial, creeping to sprawling herbs, stems succulent, with purplish dark blotches; branching monochasial or dichasial. Leaves nonsucculent, rounded and petiolate, or reduced to scales, alternate to subopposite; stipules glandular. Cyathia bisexual, solitary, terminal, pubescent, subcyathial bracts apparently lacking; glands 4 or 5, yellow-green to brown, elliptic to ovate, margin entire, exappendiculate; ovary sparsely 
pubescent, subsessile and included in the cyathium cup at maturity (E. bosseri, E. platyclada) or exserted on a recurved pedicel, impairing the development of the covered gland (E. bemarahaensis); styles 3, connate at the base, bifid almost to the base. Capsule 3-lobed, subsessile, sparsely pubescent, surface smooth. Seeds tuberculate and pointed in E. platyclada; unknown in the other two species; caruncle unknown in all three species.

Distribution and habitat. - Southwestern and southern Madagascar, in xerophytic vegetation, ca. 50-500 m.

Included species (3). - E. bemarahaensis Rauh \& R. Mangelsdorff, E. bosseri Leandri, E. platyclada Rauh.

Discussion. - These three species grow in remote areas of Madagascar and are locally rare endemics. Rauh \& Mangelsdorff (1999) placed these three species in their informal "groupe d'E. bosseri" but without a clear idea of its affinities. Cremers (1984) believed E. bosseri and E. platyclada were related to taxa like E. enterophora subsp. enterophora (subg. Euphorbia sect. Tirucalli), due to the presence of flattened twigs in both. However, this relationship is not supported by our molecular evidence.

\section{Euphorbia sect. Plagianthae T. Haevermans \& X. Aubriot, sect. nov. - Type: E. plagiantha Drake.}

Broom-like dioecious shrubs or trees with coppery-shiny bark peeling in papyraceous rings. Branches alternate, densely aggregated. Leaves scale-like and quickly deciduous (E. plagiantha) or developed and elongate (E. salota), distributed all along the twigs; stipules minute. Pistillate cyathia usually single, staminate cyathia in few-flowered cymes, on axillary branches (reduced in E. plagiantha, elongated in E. salota); subcyathial bracts green, inconspicuous in E. plagiantha, leaflike in E. salota; involucre rounded, with a sunken rim and (4-)5(-6) inconspicuous glands with an entire margin, exappendiculate; ovary glabrous; styles connate at the base, bifid at the tip. Capsules 3-lobed, smooth and glabrous, oriented upward; surface smooth, green. Seeds ovoid, apex pointed, surface smooth, ecarunculate.

Distribution and habitat. - Southern Madagascar, in xerophytic and semi-xerophytic vegetation; sea level to $1000 \mathrm{~m}$.

Included species (2). - E. plagiantha Drake, E. salota Leandri.

Discussion. - Euphorbia plagiantha is a striking tree with coppery, peeling bark and leafless, photosynthetic stems (Fig. 1A), whereas E. salota is a broom-like shrub. Euphorbia plagiantha is widely distributed in semi-xerophytic forests and shrublands, whereas E. salota is restricted to a few ridges around Betroka, northwest of Fort Dauphin. Both species share the features of peeling bark, dioecy, and capsules oriented upwards regardless of twig orientation. They also have cyathia with a shrunken rim bearing tiny reduced glands, and the cyathia are borne laterally on the distal part of the twigs, while the vegetative branching occurs on the basal part of the twigs. Euphorbia plagiantha, the only Madagascan species featuring $2 n=14$ chromosomes (Schill, 1971), was previously grouped with E. tirucalli (Cremers, 1984), but E. tirucalli belongs to subg. Euphorbia (Bruyns \& al., 2006).
9. Euphorbia sect. Frondosae Bruyns in Taxon 55: 416. 2006 - Type: E. goetzei Pax.

Annual or perennial herbs, or shrubs, tuberous in perennial species. Stems terete and semi-succulent to succulent, green and photosynthetic. Leaves alternate at base, opposite above, glabrous or pubescent, deciduous, margin entire; stipules glandular, mainly on young growth (or absent). Synflorescence of 3-5-branched terminal umbels of cymes with internodes on primary rays up to $6-12 \mathrm{~cm}$ long, bracts similar to leaves in size and shape; cyathial glands 4(5), usually bilobed (sometimes entire), or with 2-4 suberect linear processes (E. barbicollis, E. goetzei); ovary glabrous or pubescent; styles free or connate at the base, bifid up to half their length. Capsules exserted on a reflexed pedicel; 3-lobed. Seeds ovoid to oblong, apex pointed, 4-angled in cross-section; surface wrinkled to tuberculate, with or without a caruncle; caruncle shape and size varies.

Distribution and habitat. - Eastern to southern Africa (Angola, Botswana, Ethiopia, Kenya, Malawi, Mozambique, Namibia, South Africa, Tanzania, Uganda, Zambia, Zimbabwe) and the Arabian Peninsula (Oman, Saudi Arabia, Yemen); open to dense bushland, forest, $400-2700 \mathrm{~m}$.

Included species (7). - E. barbicollis P.R.O. Bally, E. engleri Pax, E. goetzei Pax, E. leistneri R.H. Archer, E. pirottae N. Terrac., E. quaitensis S. Carter, E. transvaalensis Schltr.

Discussion. - This group is characterized by being fleshy, stem photosynthetic herbs and shrubs. The umbellate rays are well-spaced with long internodes. Other species that might belong in this section include E. dolichoceras S. Carter and E. ruficeps S. Carter. Both have ecarunculate, tuberculate seeds and different kinds of cyathial gland appendages, but their placements need to be further investigated.

10. Euphorbia sect. Tenellae Pax \& K. Hoffm. in Engler, Veg. Erde 9, [Pflanzenw. Afrikas] 3, 2: 147. 1921 - Type: E. glaucella Pax (= E. glanduligera Pax).

$=$ Euphorbia subsect. Capensis Boiss. in Candolle, Prodr. 15(2): 66. 1862 - Type: E. phylloclada Boiss.

Annual or perennial herbs, stems decumbent or erect, branches few to many. Leaves all opposite, narrow to subcordate, glabrous, margin entire or denticulate; stipules subulate or inconspicuous. Cymes forking many times, bracts leaf-like. Cyathial glands 4, with petaloid appendages or exappendiculate (they may have a very thin rim on the glands); ovary glabrous or pubescent; styles free or connate at the base, tip bifid, 3-lobed. Capsule exserted on a recurved pedicel. Seeds oblong, 4-angled in cross-section, tuberculate to smooth, with a cap-like caruncle.

Distribution and habitat. - Southern Africa (Angola, Botswana, Namibia, South Africa, Zimbabwe); in open desert areas, exposed gravelly or sandy soils and rocky slopes, ca. $100-1100 \mathrm{~m}$.

Included species (4). - E. claytonioides Pax, E. glanduligera Pax (incl. E. pfeilii Pax), E. macra Hiern., E. phylloclada Boiss.

Discussion. - This is a small, but very significant section because it is sister to the rest of the mostly New World petaloid appendage clade. Pax (1921: 147) recognized its similarities to sect. Anisophyllum, and Koutnik (1984) placed E. glanduligera 
in Chamaesyce S.F. Gray (= sect. Anisophyllum) and also wondered whether E. pfeilii should belong here as well. Euphorbia pfeilii was treated as distinct from E. glanduligera by Carter \& Leach (2001), but examination of a range of specimens shows that they are all part of a single, distinctive species. We therefore include it under E. glanduligera. Apart from its extremely slender leaves, E. macra is similar to E. glanduligera, but it has a woody, perennial base.

Boissier (1862) placed E. phylloclada in E. [subg. Euphorbia] sect. Stachydium, presumably because the subcyathial bracts are so congested, but in sect. Stachydium the plants tend to be monochasial and the leaves enclose the cyathia more completely than in E. phylloclada. Later, Pax (1921) placed E. phylloclada in E. sect. Pseudacalypha Boiss., presumably because of its axillary cyathia and herbaceous habit, but the rest of sect. Pseudacalypha is now placed in subg. Rhizanthium (Steinmann \& Porter, 2002; Horn \& al., 2012a). Euphorbia claytonioides has subcordate leaves similar to E. phylloclada, but its cyathial features and the glands in the leaf axils closely resemble those of E. glanduligera. Euphorbia macra appears to be the only perennial species in this group.

\section{Euphorbia sect. Gueinziae Riina, sect. nov. - Type:} E. gueinzii Boiss.

Geophyte with tuberous roots and deciduous leaves, glabrous to densely pubescent; stems simple or multiple, branching dichotomously. Leaves usually alternate on lower portion of stem, opposite at the bifurcations of the upper branches, subsessile, lanceolate to ovate-lanceolate; stipules inconspicuous, glanduliform. Cyathia bisexual, sometimes unisexual, in terminal cymes or solitary at the bifurcation of branches; glands 5, trapezoidal or oblong-ovate, the margin entire to crenulate, without petaloid appendages; ovary usually pubescent; styles 3, connate at the base, tips bifid and spreading. Capsule exserted, subglobose, 3-lobed. Seeds oblongoid, more or less 4-angled, obscurely sculptured, pale grayish, ecarunculate.

Distribution and habitat. - South Africa (Mpumalanga, Free State, KwaZulu-Natal, Eastern Cape), Lesotho, and Swaziland; grasslands on rocky slopes and above sandstone cliffs, 200-2000 m.

Included species (1). - E. gueinzii Boiss.

Discussion. - In his treatment of E. gueinzii in Flora Capensis, Brown \& al. (1915) characterized this species as dioecious; however, Hargreaves (1992) contended that it is monoecious, sometimes presenting unisexual cyathia as well as bisexual ones. The molecular data indicate that $E$. gueinzii is related to the Brazilian E. sect. Crossadenia (Figs. 2, 3), which is consistent with its cyathial morphology and five glands, although E. gueinzii is quite distinct in its geophytic habit and inconspicuous cyathial glands. In the Euphorbia Seed Atlas (Morawetz \& al., 2010), the seed shown of E. gueinzii was misidentified, and likely belongs to subg. Rhizanthium.

12. Euphorbia sect. Crossadenia Boiss. in Candolle, Prodr. 15(2): 9, 64. 1862 - Lectotype: E. sarcodes Boiss., designated by Wheeler in Amer. Midland Naturalist 30: 481. 1943. = Euphorbia sect. Ephedropeplus Müll. Arg. in Martius, Fl.
Bras. 11(2): 668. 1874 E Euphorbia subsect. Ephedropeplus (Müll. Arg.) Müll. Arg. ex Pax in Engler \& Prantl, Nat. Pflanzenfam. 3(5): 106. 1891 - Type: E. gymnoclada Boiss.

Perennial herbs, small leafy shrubs, or pencil-stem shrubs, glabrous or pubescent, stems branching dichotomously or verticellately. Leaves opposite to alternate (spiral) on the lower stem, whorled at the base of umbellate rays, and opposite above, either rudimentary, minute, and soon deciduous, or well developed and persistent; stipules inconspicuous, glanduliform, rarely subulate. Cyathia terminal and axillary, arranged in short cymes or umbellate cymose rays, subtended by a pair of scale-like or foliose dichasial bracts. Involucres unisexual or bisexual, with 4 or 5 yellowish to green, appendiculate or exappendiculate glands; when present, gland appendages are short crenulate-dentate or long deeply cleft to fimbriate; ovary glabrous or pubescent; styles 3, basally connate, tips entire or bifid. Capsule well-exserted, subglobose to deeply 3-lobed. Seeds subglobose to ovoid, more or less 4-angled, apex mucronate, surface shallowly to obscurely tuberculate, rarely smooth, tubercles usually rounded (Fig. 1P), covered by a crustaceous, hydrophylic layer, ecarunculate.

Discussion. - The characteristic ornamentation of the seed coat, with low and rounded tubercles, may be a synapomorphy for this group. Boissier (1862) described the seeds of sect. Crossadenia as having a crustaceous caruncle, but our observations indicate that the apical part of the seed does not have a true caruncle; rather, the mucronate apex is an extension of the seed coat. The whitish layer on the outside of the seeds is hydrophilic and becomes mucilaginous when wet, much like seeds in sect. Anisophyllum. Both molecular data (Figs. 2 \& 3 ) and morphological characters support the division of this group into two subsections.

\section{Key to the subsections of $E$. sect. Crossadenia}

1 Involucral glands 5, lacking appendages or with crenulate to dentate appendages $<0.2 \mathrm{~mm}$ long $\ldots \ldots \ldots \ldots \ldots \ldots$ 12a. subsect. Apparicianae

1 Involucral glands 4 (5 in E. gymnoclada), with multiple finger-like appendages $2-4 \mathrm{~mm}$ long ................. 12b. subsect. Sarcodes

12a. Euphorbia subsect. Apparicianae Riina, subsect. nov. Type: E. appariciana Rizzini.

Stem leaves rudimentary and soon deciduous. Involucral glands 5, gland appendages crenate to dentate, teeth $<0.2 \mathrm{~mm}$ long, or appendages lacking (E. flaviana).

Distribution and habitat. - Endemic to the state of Bahia, Brazil, growing on granitic domes (inselbergs) or sandstone outcrops, 250-1200 m.

Included species (3). - E. appariciana Rizzini, E. flaviana Carn.-Torres \& Cordeiro (Carneiro-Torres \& al., 2012), E. teres M. Machado \& Hofacker.

12b. Euphorbia subsect. Sarcodes Riina, subsect. nov. - Type: E. sarcodes Boiss.

Stem leaves usually well developed and persistent (rudi- 
mentary and deciduous in E. gymnoclada). Involucral glands 4 (5 in E. gymnoclada) with white, finger-like appendages, teeth 2-4 mm long.

Distribution and habitat. - Endemic to eastern-central Brazil (Bahia, Goiás, Minas Gerais, Distrito Federal, Pernambuco, Piauí), in "campo rupestre" vegetation on sandy substrates and coastal "restinga", sea level to $1400 \mathrm{~m}$.

Included species (6). - E. crossadenia Pax \& K. Hoffm., E. goyazensis Boiss., E. gymnoclada Boiss., E. lycioides Boiss., E. sarcodes Boiss., E. sessilifolia Klotzsch ex Boiss.

13. Euphorbia sect. Anisophyllum Roep. in Duby, Bot. Gall., ed. 2, 1: 412. $1828 \equiv$ Anisophyllum Haw., Syn. Pl. Succ.: 159. 1812, nom. illeg., non Jacq. 1763 三 Chamaesyce Gray, Nat. Arr. Brit. Pl. 2: 260. $1821 \equiv$ Euphorbia subg. Chamaesyce (Gray) Caesalp. ex. Rchb., Deut. Bot. Herb.Buch.: 193. 1841, nom. illeg., non Raf. 1817 - Lectotype: Euphorbia peplis L. ( $\equiv$ Anisophyllum peplis (L.) Haw. $\equiv$ Chamaescye maritima Gray, nom. illeg., Art. 52.1) designated by Wheeler in Rhodora 43: 111. 1941.

= Aplarina Raf., New Fl. 4: 99.1838 - Lectotype: A. prostrata Raf. (=E. prostrata Aiton), designated by Wheeler in Rhodora 43: 111. 1941.

$=$ Ditritra Raf., Sylva Tellur.: 115. 1838 - Lectotype: $D$. hirta (L.) Raf. (三E. hirta L.), designated by Wheeler in Amer. Midland Naturalist 30: 464. 1943.

= Endoisila Raf., Sylva Tellur.: 114. 1838 - Type: Endoisila myrsinites Raf. (= E. myrtillifolia L.). See Wheeler (in Amer. Midland Naturalist 30: 465. 1943) for explanation of Rafinesque's confusion over the specific epithet of the type species.

=Xamesike Raf., Fl. Tellur. 4: 115. 1838 - Lectotype: X. vulgaris Raf. (=E. chamaesyce L.), designated by Wheeler in Amer. Midland Naturalist 30: 476. 1943.

Annual or perennial herbs, rarely subshrubs to shrubs. Branches many, dichotomous, prostrate or ascending, rarely erect; main shoot aborts above the cotyledon node (less often continues growing for a few more nodes) and lateral shoots branch dichotomously. Leaves opposite, glabrous or pubescent, base often asymmetrical; sometimes dark green veins are visible on leaf blades; margins entire or serrate; stipules interpetiolar, glandular, linear, or subulate to triangular. Cyathia solitary at the bifurcation of branches or clustered in axillary cymes; glands 4, rarely 5-7; appendages present or absent, petaloid when present; styles 3, free or connate at the base, tip bifid, rarely entire; ovary and capsule glabrous or pubescent. Seed surface with transverse ridges, smooth, or with irregular wrinkles; 4-angled (rarely 3-angled or rounded), ecarunculate. $\mathrm{C}_{2}, \mathrm{C}_{3}$ or $\mathrm{C}_{4}$ photosynthesis.

Distribution and habitat. - Warm, arid and semi-arid vegetation or disturbed habitats, and summer annuals of temperate areas; nearly worldwide, sea level to $4000 \mathrm{~m}$.

Discussion. - Section Anisophyllum is characterized by its specialized growth form with early abortion of the main shoot and with the lateral shoots producing exclusively opposite leaves. All but three species in the section have $\mathrm{C}_{4}$ photosynthesis.

\section{Key to the subsections of $E$. sect. Anisophyllum}

1 Stipules glandular; leaf cross-section without typical Kranz anatomy; cyathial gland appendages crenate and fan-shaped; Texas, New Mexico, and northern Mexico .

13a. subsect. Acutae

1 Stipules subulate, triangular or ciliate, non-glandular; leaf cross-section with Kranz anatomy; cyathial gland appendages absent or present (varioulsy shaped); widespread distribution ................... 13b. subsect. Hypericifoliae

13a. Euphorbia subsect. Acutae Boiss. in Candolle, Prodr. 15(2): 18. 1862 - Type: E. acuta Engelm.

Perennial, pubescent herbs with a thickened woody taproot. Stems prostrate, arching, ascending to erect. Leaves opposite, or occasionally annual shoots terminate with a whorl in E. angusta; margin entire; stipules glandular. Cyathia solitary at the bifurcation of branches; glands 4, appendages fan-shaped, equal in size; ovary and capsule pubescent, 3-lobed; styles bifid. Seeds ovoid, 4-angled; face smooth, with irregular shallow depressions, or obscurely transversely rugose. $\mathrm{C}_{2}$ or $\mathrm{C}_{3}$ photosynthesis.

Distribution and habitat. - U.S.A. (western Texas) and Mexico (Coahuila, Durango, Tamaulipas); grassland to desert scrub in and around the Chihuahuan Desert on sandy or gravelly limestone substrates, $200-1500 \mathrm{~m}$.

Included species (3). - E. acuta Engelm., E. angusta Engelm., E. johnstonii Mayfield.

Discussion. - Subsection Acutae is diagnosed within the section by having glandular stipules and lacking $\mathrm{C}_{4}$ photosynthesis.

13b. Euphorbia subsect. Hypericifoliae Boiss. in Candolle, Prodr. 15(2): 20. 1862 - Type: E. hypericifolia L.

$=$ Euphorbia subsect. Chamaesyce Boiss. in Candolle, Prodr. 15(2): 27. 1862, nom. illeg. per ICBN Art. 53.4 - Type: E. chamaesyce L.

$=$ Euphorbia subsect. Cheloneae Boiss. in Candolle, Prodr. 15(2): 16. 1862 - Lectotype: E. nummularia Hook.f., designated by Wheeler in Rhodora 43: 111. 1941.

$=$ Euphorbia subsect. Elegantes Boiss. in Candolle, Prodr. 15(2): 18. 1862 - Type: E. elegans Spreng.

$=$ Euphorbia subsect. Gymnadeniae Boiss. in Candolle, Prodr. 15(2): $11.1862 \equiv$ Chamaesyce subsect. Gymnadeniae (Boiss.) Koutnik in Allertonia 4: 338. 1987 - Lectotype: E. clusiifolia Hook. \& Arn., designated by Wheeler in Amer. Midland Naturlist 30: 480. 1943.

$=$ Euphorbia subsect. Pleiadeniae Boiss. in Candolle, Prodr. 15(2): 50. 1862 - Lectotype: E. selloi (Klotzsch \& Garcke) Boiss., designated by Wheeler in Amer. Midland Naturalist 30: 480. 1943.

$=$ Euphorbia subsect. Sclerophyllae Boiss. in Candolle, Prodr. 15(2): $12.1862 \equiv$ Euphorbia sect. Sclerophyllae (Boiss.) Binojk. \& N.P. Balakr., Genus Euphorbia India: 201. 2010 $\equiv$ Chamaesyce Gray sect. Sclerophyllae (Boiss.) Hurusawa in J. Fac. Sci. Univ. Tokyo, Sect. 3, Bot. 6: 275. 1954 - Lectotype: E. atoto G. Forst., designated by Wheeler in Amer. Midland Naturalist 30: 480. 1943. 
= Euphorbia sect. Longistylae Binojk. \& N.P. Balakr., Genus Euphorbia India: 178. 2010 - Type: E. longistyla Boiss.

Annual or perennial herbs, rarely subshrubs to shrubs. Branches many, dichotomous, prostrate or ascending, rarely erect; main shoot aborts above the cotyledon node (less often continues elongation) and lateral shoots branch dichotomously. Leaves opposite, glabrous or pubescent, base often asymmetrical; sometimes dark green veins are visible on leaf blades (Kranz anatomy); margins entire or serrate; stipules interpetiolar, linear, subulate to triangular. Cyathia solitary at the bifurcation of branches, or clustered in axillary cymes; glands 4, rarely 5-7; appendages present or absent, petaloid when present, equal or unequal in size; styles 3, free or connate at the base, tip bifid, rarely entire; ovary and capsule glabrous or pubescent. Seed surface with transverse ridges, smooth, or with irregular wrinkles; 4-angled (rarely 3-angled or rounded). $\mathrm{C}_{4}$ photosynthesis.

Distribution and habitat. - Warm, arid and semi-arid vegetation or disturbed habitats, and summer annuals in temperate areas; worldwide, from sea level to $4000 \mathrm{~m}$.

Included species (365). - E. abdita (D.G. Burch) Radcl.Sm., E. abdulghafooriana Abedin, E. abramsiana L.C. Wheeler, E. adenoptera Bertol., E. alainii Oudejans, E. alatocaulis V.W. Steinm. \& Felger, E. albomarginata Torr. \& A. Gray, E. allocarpa S. Carter, E. alsiniflora Baill., E. alsinifolia Boiss., E. amandi Oudejans, E. amplexicaulis Hook. f., E. anisopetala (Prokh.) Prokh., E. anthonyi Brandegee, E. anychioides Boiss., E. apatzingana McVaugh, E. apicata L.C. Wheeler, E. arabica Hochst. \& Steud. ex Anderson, E. arabicoides N.E. Br., E. arenarioides Gagnep., E. argillosa Chodat \& Hassl., E. arizonica Engelm., E. armstrongiana Boiss., E. arnottiana Endl., E. articulata Aubl., E. astyla Engelm. ex Boiss., E. atoto G. Forst., E. atrococca A. Heller, E. australis Boiss., E. austrooccidentalis Thell., E. bahiensis (Klotzsch \& Garcke) Boiss., E. balakrishnanii Binojk. \& Gopalan, E. bartolomaei Greene, E. baueri Engelm. ex Boiss., E. berteroana Balb. ex Spreng., E. besseri (Klotzsch \& Garcke) Boiss., E. biconvexa Domin, E. bifida Hook. \& Arn., E. bindloensis (Stewart) Y. Yang, E. blodgettii Engelm. ex Hitchc., E. boliviana Rusby, E. bombensis Jacq., E. bracteolaris Boiss., E. brandegeei Millsp., E. bruntii (Proctor) Oudejans, E. burchellii Müll. Arg., E. burmanica Hook. f., E. calderoniae V.W. Steinm., E. camagueyensis (Millsp.) Urb., E. capillaries Gagnep., E. capitellata Engelm., E. carissoides F.M. Bailey, E. carunculata Waterf., E. catamarcensis (Croizat) Subils, E. cayensis Millsp., E. celastroides Boiss., E. centralis B.G. Thomson, E. centunculoides Kunth, E. chaetocalyx (Boiss.) Tidestr., E. chamaerrhodos Boiss., E. chamaesyce L., E. chamaesycoides B. Nord., E. chamberlinii I.M. Johnst., E. chamissonis (Klotzsch \& Garcke) Boiss., E. cinerascens Engelm., E. clarkeana Hook. f., E. clavidigitata Gage, E. clusiifolia Hook. \& Arn., E. coccinea B. Heyne ex Roth, E. coghlanii F.M. Bailey, E. compressa Boiss., E. concanensis M.K. Janarth. \& S.R. Yadav, E. conferta (Small) B.E. Sm., E. convolvuloides Hochst. ex Benth., E. cordifolia Elliott, E. corrigioloides Boiss., E. cowellii (Millsp. ex Britton) Oudejans, E. cozumelensis Millsp., E. crassinodis Urb., E. crepitata
L.C. Wheeler, E. crepuscula (L.C. Wheeler) V.W. Steinm. \& Felger, E. cristata B. Heyne ex Roth, E. cumbrae Boiss., E. cumulicola (Small) Oudejans, E. dallachyana Baill., E. deccanensis V.S. Raju, E. degeneri Sherff, E. delicatissima S. Carter, E. deltoidea Engelm. ex Chapm., E. densiflora (Klotzsch and Garcke) Klotzsch, E. dentosa I.M. Johnst., E. deppeana Boiss., E. derickii V.W. Steinm., E. diminuta S. Carter, E. dioeca Kunth, E. drummondii Boiss., E. duckei (Croizat) Oudejans, E. eichleri Müll. Arg., E. eleanoriae (D.H. Lorence \& W.L. Wagner) Govaerts, E. elegans Spreng., E. engelmannii Boiss., E. erythroclada Boiss., E. eylesii Rendle, E. feddemae McVaugh, E. fendleri Torr. \& A. Gray, E. fischeri Pax, E. flindersica Halford \& W.K. Harris, E. floribunda Engelm. ex Boiss., E. florida Engelm., E. foliolosa Boiss., E. fosbergii (J. Florence) Govaerts, E. fruticulosa Engelm. ex Boiss., E. galapageia B.L. Rob. \& Greenm., E. garanbiensis Hayata, E. garberi Engelm. ex Chapm., E. gaudichaudii Boiss., E. geyeri Engelm. \& A. Gray, E. glyptosperma Engelm., E. goliana Comm. ex Lam., E. golondrina L.C. Wheeler, E. gracillima S. Watson, E. grammata (McVaugh) Oudejans, E. grandidieri Baill., E. granulata Forssk., E. guanarensis Pittier, E. hajhirensis Radcl.-Sm., E. halemanui Sherff, E. heleniana Thell. \& Stapf, E. helwigii Urb. \& Ekman, E. hepatica Urb. \& Ekman, E. herbstii (W.L. Wagner) Oudejans, E. heyneana Spreng., E. hildebrandtii Baill., E. hirta L., E. hirtella Boiss., E. hispida Boiss., E. hooveri L.C. Wheeler, E. hsinchuensis (S.C. Lin \& S.M. Chaw) C.Y. Wu \& J.S. Ma, E. humbertii Denis, E. humifusa Willd., E. humistrata Engelm. ex A.Gray, E. hunzikeri Subils, E. hypericifolia L., E. hyssopifolia L., E. inaequilatera Sond., E. inaguaensis Oudejans, E. inappendiculata Domin, E. incerta Brandegee, E. indica Lam., E. indivisa (Engelm.) Tidestr., E. infernidialis V.W. Steinm., Euphorbia inflexa Urb. \& Ekman, Euphorbia jaegeri V.W. Steinm. \& J. André, E. jamesonii Boiss., E. jejuna M.C. Johnst. \& Warnock, E. jodhpurensis Blatt. \& Hallb., E. karibensis S. Carter, E. katrajensis Gage, E. kerstingii Pax, E. kilwana N.E. Br., E. kimberleyensis B.G. Thomson, E. kischenensis Vierh., E. klotzschii Oudejans, E. kuriensis Vierh., E. kuwaleana O. Deg. \& Sherff, E. laciniata Panigrahi, E. laredana Millsp., E. lasiocarpa Klotzsch, E. lata Engelm., E. lawsonii Binojkumar \& Dwarakan, E. lecheoides Millsp., E. leonardii (D.G. Burch) Radcl.-Sm., E. leptoclada Balf.f., E. leucantha (Klotzsch \& Garcke) Boiss., E. leucophylla Benth., E. lineata S. Watson, E. linguiformis McVaugh, E. lissosperma S. Carter, E. liukiuensis Hayata, E. livida E. Mey. ex Boiss., E. loandensis N.E. Br., E. longinsulicola S.R. Hill, E. longistyla Boiss., E. lupatensis N.E. Br., E. lutulenta (Croizat) Oudejans, E. luzoniensis Merr., E. macgillivrayi Boiss., E. machrisiae Steyerm., E. maconochieana B.G. Thomson, E. maculata L., E. magdalenae Benth., E. makinoi Hayata, E. marayensis Subils, E. meganaesos Featherman, E. melanadenia Torr. \& A. Gray, E. mendezii Boiss., E. mertonii Fosberg, E. mesembryanthemifolia Jacq., E. meyeniana Klotzsch, E. microcephala Boiss., E. micromera Boiss., E. minbuensis Gage, E. minutula Boiss., E. missurica Raf., E. mitchelliana Boiss., E. mossambicensis (Klotzsch \& Garcke) Boiss., E. mossamedensis N.E. Br., E. muelleri Boiss., E. multiformis Gaudich. ex Hook. \& Arn., E. multinodis Urb., 
E. myrtillifolia L., E. neocaledonica Boiss., E. neopolycnemoides Pax \& K. Hoffm., E. nocens (L.C. Wheeler) V.W. Steinm., E. nodosa Houtt., E. notoptera Boiss., E. nummularia Hook. f., E. nutans Lag., E. obliqua F.A. Bauer ex Endl., E. occidentaustralica Radcl.-Sm. \& Govaerts, E. ocellata Durand \& Hilg., E. olowaluana Sherff, E. ophiolitica (P.I. Forst.) Y. Yang, E. ophthalmica Pers., E. oranensis (Croizat) Subils, E. orbiculata Kunth, E. orbifolia (Alain) Oudejans, E. origanoides L., E. oxycoccoides Boiss., E. pancheri Baill., E. parciflora Urb., E. paredonensis (Millsp.) Oudejans, E. parishii Greene, E. parkeri Binojkumar \& N.P. Balakr., E. parryi Engelm., E. parva N.E. Br., E. parviflora L., E. pediculifera Engelm., E. pellegrinii Leandri, E. peninsularis I.M. Johnst., E. peplis L., E. perennans (Shinners) Warnock \& M.C. Johnst., E. pergamena Small, E. pergracilis P.G. Mey., E. perlignea McVaugh, E. peruviana L.C. Wheeler, E. petrina S. Watson, E. picachensis Brandegee, E. pilosissima S. Carter, E. pionosperma V.W. Steinm. \& Felger, E. platysperma Engelm. ex S. Watson, E. podadenia Boiss., E. polycarpa Benth., E. polycnemoides Hochst. ex Boiss., E. polygonifolia L., E. pondii Millsp., E. porteriana (Small) Oudejans, E. portucasadiana (Croizat) Subils, E. potentilloides Boiss., E. potosina Fernald, E. proctori (D.G. Burch) Correll, E. prostrata Aiton, E. psammogeton P.S. Green, E. pueblensis Brandegee, E. punctulata Andersson, E. pycnostegia Boiss., E. quitensis Boiss., E. radioloides Boiss., E. ramosa Seaton, E. rayturneri V.W. Steinm. \& E. Jercinovic, E. reconciliationis Radcl.-Sm., E. recurva Hook. f., E. remyi A. Gray ex Boiss., E. reniformis Blume, E. revoluta Engelm., E. rhytisperma (Klotzsch \& Garcke) Boiss., E. riebeckii Pax, E. rivae Pax, E. rochaensis (Croizat) Alonso Paz \& Marchesi, E. rockii C.N. Forbes, E. rosea Retz., E. rubriflora N.E. Br., E. ruiziana (Klotzsch \& Garcke) Boiss., E. ruizlealii Subils, E. rutilis (Millsp.) Standl. \& Steyerm., E. sabulicola Boiss., E. sachetiana (J. Florence) Govaerts, E. salsicola S. Carter, E. salsuginosa (McVaugh) Radcl.-Sm. \& Govaerts, E. sanmartensis Rusby, E. scabrifolia Kurz, E. schizolepis F. Muell. ex Boiss., E. schlechteri Pax, E. schultzii Benth., E. schumannii Radcl.-Sm., E. schweinfurthii Balf.f., E. scopulorum Brandegee, E. scordiifolia Jacq., E. sebastinei Binojk. \& N.P. Balakr., E. seleri Donn. Sm., E. selloi (Klotzsch \& Garcke) Boiss., E. selousiana S. Carter, E. senguptae N.P. Balakr. \& Subr., E. serpens Kunth, E. serpyllifolia Pers., E. serratifolia S. Carter, E. serrula Engelm., E. setiloba Engelm. ex Torr., E. setosa (Boiss.) Müll. Arg., E. sharkoensis Baill., E. simulans (L.C. Wheeler) Warnock \& M.C. Johnst., E. skottsbergii Sherff, E. sparrmanii Boiss., E. sparsiflora A. Heller, E. spellenbergiana Mayfield \& V.W. Steinm., E. spissiflora S. Carter, E. standleyi (Millsp.) Oudejans, E. stictospora Engelm., E. stoddartii Fosberg, E. subterminalis N.E. Br., E. sumbawensis Boiss., E. taihsiensis (Chaw \& Koutnik) Oudejans, E. taluticola Wiggins, E. tamanduana Boiss., E. tamaulipasana (Millsp.) Oudejans, E. tettensis Klotzsch, E. theriaca L.C. Wheeler, E. thymifolia L., E. tinianensis Hosok., E. tomentella Engelm. ex Boiss., E. tomentulosa S. Watson, E. torralbasii Urb., E. trachysperma Engelm., E. trancapatae (Croizat) J.F. Macbr., E. trialata (Huft) V.W. Steinm., E. trichophylla Baker, E. trinervia
Schumach. \& Thonn., E. tumistyla (D.G. Burch) Radcl.-Sm., E. turpinii Boiss., E. umbellulata Engelm. ex Boiss., E. vaginulata Griseb., E. vallis-mortae (Millsp.) J.T. Howell, E. vauthieriana Boiss., E. velleriflora (Klotzsch \& Garcke) Boiss., E. velligera Schauer, E. vermiculata Raf., E. vestita Boiss., E. vezorum Leandri, E. viatilis Ule, E. villifera Scheele, E. viminea Hook. f., E. viridula Cordem. ex Radcl.-Sm., E. viscoides Boiss., E. wheeleri Baill., E. yucatanensis (Millsp.) Standl., E. zambesiana Benth.

Discussion. - Old World species of subsect. Hypericifoliae are relatively understudied and there may be additional species to be described as well as others to be placed in synonymy. Currently David Halford (BRI) is revising the group in Australia and has numerous new species he plans to name and publish as part of that revision.

The following combinations are made here to recognize the taxa at the appropriate rank within Euphorbia:

Euphorbia bindloensis (Stewart) Y. Yang, comb. nov. $\equiv E u$ phorbia articulata var. bindloensis Stewart in Proc. Calif. Acad. Sci., ser. 4, 1: 91. 1911 EChamaesyce bindloensis (Stewart) D.G. Burch in Ann. Missouri Bot. Gard. 56: 176. 1969 - Type: Ecuador. Galapagos: Bindloe Island, Stewart 1968 (holotype: GH).

Euphorbia deltoidea subsp. serpyllum (Small) Y. Yang, comb. nov. $\equiv$ Chamaesyce serpyllum Small, Fl. Florida Keys: 81. $1913 \equiv$ Chamaesyce deltoidea subsp. serpyllum (Small) D.G. Burch in Ann. Missouri Bot. Gard. 53: 99. $1966 \equiv E u-$ phorbia deltoidea var. serpyllum (Small) Oudejans in Phytologia 67: 45. 1989 - Type: U.S.A. Florida: Big Pine Key, Monroe County, J.K. Small 3811 (holotype: NY). — This new combination is made to be consistent in recognizing four subspecies within the Euphorbia deltoidea complex.

Euphorbia ophiolitica (P.I. Forst.) Y. Yang, comb. nov. $\equiv$ Chamaesyce ophiolitica P.I. Forst. in Austrobaileya 5: 711. 2000 - Type: Australia. Queensland: Port Curtis District, P.I. Forster 15042 (holotype: BRI).

14. Euphorbia sect. Poinsettia (Graham) Baill., Étude Euphorb.: 284. 1858 E Poinsettia Graham in Edinburgh New Philos. J. 20: 412. 1836 E Euphorbia subg. Poinsettia (Graham) House in Bull. New York State Mus. Nat. Hist. 254: 473. 1924 - Type: Poinsettia pulcherrima (Willd.) Graham (三E. pulcherrima Willd.).

= Cyathophora Raf., Fl. Tellur. 4: 117. 1838 - Type: C. heterophylla (Raf.) L. (三E. heterophylla L.).

= Pleuradena Raf., Atlantic J. 1: 182. 1833 E Euphorbia subg. Pleuradena (Raf.) Croizat in Revista Sudamer. Bot. 6: 10 1939 - Type: Pleuradena coccinea Raf. (=E. pulcherrima Willd.).

Annual or perennial herbs, shrubs, or small trees, from a taproot or tuber. Earliest developing leaves and branches opposite, middle to upper nodes alternate or opposite/whorled, blades usually markedly to finely serrate, rarely entire, sometimes markedly heteromorphic; stipules minute, glanduliform, 
often inconspicuous. Cyathia few to many in usually congested, terminal cymes, sometimes appearing corymbiform, leafy bracts sometimes whitish to bright red at the base or on the entire blade; cyathial glands $1-5(-8)$, slightly concave to deeply cupped, bilabiate, or circular, appendages lacking or present and variously shaped; styles 3 , free or connate at the base, tip entire or bifid; ovary and capsule glabrous or pubescent, 3-lobed. Seeds 4-angled to rounded, sharply 4-angled to somewhat rounded in cross-section, usually truncate apically, variously tuberculate, with or without a caruncle.

Discussion. - Species of the first two diverging subsections (subsects. Lacerae and Erianthae) are distinct in their large caruncles and sharply 4-angled seeds. The seeds of subsect. Exstipulatae, in contrast, are similar to many of those in subsect. Stormieae, which have a coarsely tuberculate surface, more ovoid shape, and are either carunculate or ecarunculate. See additional discussion in the main text for an expanded justification for the broadened circumscription of sect. Poinsettia.

\section{Key to the subsections of $E$. sect. Poinsettia}

1 Leaves linear, mostly entire; involucral glands densely appressed-pubescent, with laciniate, pubescent appendages that arch upwards and inwards over the gland ...... 14b. subsect. Erianthae

1 Leaves linear to pandurate and usually toothed (entire in E. colorata); involucral glands either lacking appendages or the appendages not covering the glands ............. 2

2 Involucral glands 4, appendages either horned or petaloid and green with crenate margins; styles entire; seeds sharply 4-angled, finely tuberculate, with a prominent stipitate caruncle nearly as wide as the seed itself .......

..............................14a. subsect. Lacerae

2 Involucral glands 1-5(-8), lacking appendages or, if present, then appendages whitish (green and obsolete in E. chersonesa), petaloid and not horned; styles bifid; seeds not sharply 4-angled, apically depressed on the ventral side, coarsely tuberculate, either ecarunculate or with a small caruncle much narrower than the seed ........... 3

3 Involucral glands with whitish appendages ............. ......................... 14c. subsect. Exstipulatae

3 Involucral glands without appendages (or obsolete greenish appendages in E. chersonesa) ... 14d. subsect. Stormieae

14a. Euphorbia subsect. Lacerae Y. Yang \& P.E. Berry, subsect. nov. - Type: Euphorbia lacera Boiss.

Annual herbs from a taproot. Leaves linear-lanceolate to pandurate, often heteromorphic, noticeably serrate, opposite at lowest nodes, then alternate in the mid-section, the shoot terminating with a whorl of leaves below the fertile branches; stipules absent or glandular. Cyathia in terminal, congested, few-cyathiate cymes, subtended by opposite leaves; glands 4, stipitate, laterally compressed and concave; appendages horned, or petaloid and green with crenate margins; styles entire; ovary and capsule oblong-ovoid. Seeds 4-angled, apically angled, finely tuberculate, with a prominent stipitate caruncle nearly as wide as the seed itself.
Distribution and habitat. - Central and western Mexico; xerophytic scrub, wooded ravines, $900-2500 \mathrm{~m}$.

Included species (2). - E. jaliscensis B.L. Rob. \& Greenm., E. lacera Boiss.

Discussion. - The pandurate, serrate leaves of E. jaliscencis are remarkably similar to those found in E. heterophylla or E. cyathophora, and the leaves of E. lacera are also polymorphic. Both species in this section have cupped, stipitate involucral glands. In both cases, the appendages are green and somewhat fleshy, although they are much reduced and almost obsolete in the type of E. jaliscensis var. durangensis Millsp. Euphorbia lacera was initially placed by Boissier (1862) in E. sect. Zygophyllidium, together with E. exstipulata in an undesignated subcategory of $\S$ Carunculatae Boiss. The rest of Boissier's section consists of $\S$ Ecarunculatae Boiss., with two species that belong now to sect. Alectoroctonum, E. bilobata and E. hexagona.

14b. Euphorbia subsect. Erianthae Y. Yang \& P.E. Berry, subsect. nov. - Type: Euphorbia eriantha Benth.

Annual or short-lived, pubescent, perennial herbs from a taproot. Branches few to many from the base. Leaves linear, appearing entire but usually with a few inconspicuous teeth towards the apex, opposite at basal-most node, alternate in the mid-section; stipules inconspicuous, minute and glanduliform, at the base of the petiole. Cyathia in terminal, congested, fewcyathiate cymes, subtended by opposite or ternate, leaf-like bracts; glands (2-)4-5, protruding from the outer, upper edge of the involucre, shallowly concave; gland appendages elongate, laciniate, densely covered with white, appressed trichomes, arching over and concealing the glands (Fig. 1H); styles free at the base, apex entire, purple; ovary and capsule canescent, obloid or ovoid. Seeds 4-angled, coarsely tuberculate, covered with a white, crustaceous coating, with a circular caruncle about half as wide as the seed.

Distribution and habitat. - Southeastern U.S.A. (Arizona, California, New Mexico, Texas) and northern Mexico (Baja California, Baja California Sur, Chihuahua, Coahuila, Durango, Sonora); desert scrub and thorn scrub on rocky slopes and along washes, sea level to $900 \mathrm{~m}$.

Included species (1). $-\boldsymbol{E}$. eriantha Benth.

Discussion. - This subsection contains a single species that is unique because of its unusual cyathial gland appendages that curl over the gland towards the inside of the cyathium (Fig. 1H).

14c. Euphorbia subsect. Exstipulatae Y. Yang \& P.E. Berry, subsect. nov. - Type: E. exstipulata Engelm.

Small, annual herbs from a slender taproot, with opposite, arcuate branching. Leaves linear to ovate, serrate, opposite throughout or with some alternate leaves in the mid-stem section in E. bifurcata. Cyathia in terminal, congested fewcyathiate cymes; glands 1-4(-5), oblong to circular, stipitate, laterally compressed and concave, appendages entire, undulate, or divided into triangular segments; styles bifid; ovary and capsule glabrous or pubescent on the keels, 3-lobed. Seeds broadly ovoid, apically depressed on the ventral side, quadrangular to rounded in cross-section, coarsely tuberculate with 2 transverse 
ridges and a tiny, reniform caruncle (in E. exstipulata), or warty-papillate without an evident caruncle (E. bifurcata).

Distribution and habitat. - Southwestern U.S.A. to southern Mexico; desert scrub, grasslands, oak forest, riparian areas, 800-2300 m.

Included species (2). - E. bifurcata Engelm., E. exstipulata Engelm.

Discussion. - Euphorbia bifurcata is very similar to many species in subsect. Stormieae in its normally single cupulate gland, some subcyathial bracts that are whitish at the base, and its ecarunculate, verrucose seeds. Euphorbia exstipulata was initially placed by Boissier (1862) in E. sect. Zygophyllidium, together with $E$. lacera in a subdivision named § Carunculatae Boiss.

14d. Euphorbia subsect. Stormieae Croizat in Revista Sudamer. Bot. 6: 13. 1939 - Type: Euphorbia stormiae Croizat ( $\equiv$ E. radians Benth. var. stormiae (Croizat) Rzed. \& Calderón).

Annual or perennial herbs, shrubs or small trees. Branches opposite; leaves opposite at the epicotyledonary node, leaves and branches often alternate in the mid-section of plant, and then opposite or whorled in the synflorescence; leaves subtending the synflorescence often brightly colored. Cyathia in terminal, usually dense, sometimes monochasial cymes; involucral glands 1-5(-8), deeply to shallowly cupped and stalked, exappendiculate; styles 3 , free or connate at the base, bifid to about $1 / 2$ their length from the apex, rarely entire or with only the very apex forked; ovary and capsule glabrous or pubescent, 3 -lobed. Seeds ovoid, quadrangular or somewhat rounded in cross-section, usually coarsely and unevenly tuberculate, or the tubercles disposed in one or more transverse, dorsal rows; ecarunculate, or caruncle variously shaped.

Distribution and habitat. - Widespread in the New World, from Canada to Argentina, but with a center of distribution in Mexico; in a wide variety of habitats from desert scrub to moist montane forests, sea level to $2700 \mathrm{~m}$.

Included species (21). - E. chersonesa Huft, E. colorata Engelm., E. cornastra (Dressler) Radcl.-Sm., E. cuphosperma (Engelm.) Boiss., E. cyathophora Murray, E. davidii Subils, E. dentata Michx., E. elliptica Lam., E. heterophylla L., E. hormorrhiza Radcl.-Sm., E. kurtzii Subils, E. pentadactyla Griseb., E. pinetorum (Small) G.L. Webster, E. pulcherrima Willd., E. pumicicola Huft, E. radians Benth., E. restiacea Benth., E. schiedeana (Klotzsch \& Garcke) Mayfield ex C. Nelson, E. strigosa Hook. \& Arn., E. tubadenia Mayfield ex Y. Yang, E. zonosperma Müll. Arg.

Discussion. - This subsection is the most diverse in sect. Poinsettia in terms of distribution, habit, and species number. It includes the species that Dressler (1961) included in Poinsettia, and those in Euphorbia subg. Poinsettia sensu Mayfield (1997), with the addition of E. chersonesa, which Huft (1984) thought belonged to sect. Alectoroctonum because of its vestigial involucral gland appendages and relatively flat glands. Vestigial green gland appendages were reported in E. chersonesa and E. cornastra (Huft, 1984; Mayfield, 1997), but they are very subtle and difficult for us to see when reexamining herbarium material of these species. Mayfield (1997) recognized two groups in subg. Poinsettia, the Euphorbia dentata alliance and "subgenus Poinsettia sens.str." Our combined molecular tree (Fig. 3B) indicates that the E. dentata alliance may be monophyletic, but it is nested within the rest of the subsection.

In addition to the species listed above, there are four other species described but not validly published in Mayfield's (1997) thesis. In addition, Mayfield (1997) proposed a new name and status for another species he recognized in subg. Poinsettia. This name is validated below.

Euphorbia tubadenia Mayfield ex Y. Yang, nom. \& stat. nov. $\equiv$ Euphorbia dentata var. lasiocarpa Boiss. in Candolle, Prodr. 15(2): 72. 1862 - Type: Mexico. Nuevo León: Tanquesillos, Jul-Oct 1842, W.F. von Karwinski s.n. (holotype: LE). - Since the epithet lasiocarpa is occupied in Euphorbia (E. lasiocarpa Klotzsch), a new name is required for this taxon when elevated to species.

15. Euphorbia sect. Alectoroctonum (Schltdl.) Baill., Étude Euphorb.: 284. $1858 \equiv$ Alectoroctonum Schltdl. in Linnaea 19: 252. 1847 - Lectotype: A. scotanum (Schltdl.) Schltdl. ( $\equiv$ E. scotanum Schltdl.), designated by Wheeler in Amer. Midland Naturalist 30: 459. 1943.

= Agaloma Raf., Fl. Tellur. 4: 116. $1838 \equiv$ Euphorbia subg. Agaloma (Raf.) House in Bull. New York State Mus. Nat. Hist. 254: 471. 1924 - Lectotype: E. corollata L., designated by Rafinesque in Autik. Bot: 95. 1840.

$=$ Tithymalopsis Klotzsch \& Garcke in Monatsber. Königl. Preuss. Akad. Wiss. Berlin 1859: 249. 1859 三Euphorbia sect. Tithymalopsis (Klotzsch \& Garcke) Boiss. in Candolle, Prodr. 15(2): 9, 66. 1862 - Lectotype: E. corollata L., designated by Small in Britton \& Brown, Ill. Fl. N.U.S., ed. 2., 2: 469. 1913.

= Zalitea Raf., New Fl. 4: 98.1838 - Type: Z. linearis Raf. (=E. hexagona Nutt.).

$=$ Euphorbia sect. Zygophyllidium Boiss. in Candolle, Prodr. 15(2): 9, 52. 1862 E Zygophyllidium (Boiss.) Small in Fl. S.E. U.S.: 714, 1334. 1903 - Lectoype: Z. hexagonum ( $\equiv$ E. hexagona Nutt.), designated by Small in Britton \& Brown, Ill. Fl. N.U.S., ed. 2., 2: 468. 1913.

Annual or perennial herbs, shrubs, rarely succulent or small trees. Stems erect to decumbent, rarely prostrate. Leaves and branches opposite and/or alternate before the termination of apical growth, which usually produces a 2-8-rayed pseudoumbel and usually equal number of leaves (sometimes there is no apical termination and the main shoots continue elongating), and then switching to dichotomous branching, with each fork subtended by a pair of dichasial bracts. Leaves elliptic, ovate, obovate to linear, margin entire, rarely crenulate; stipules mostly minute and glanduliform, rarely subulate-filiform. Cyathia solitary or in cymes, terminal or axillary; both dichasial and subcyathial bracts leaf-like, sometimes greatly reduced in size, or white and showy; glands 5 per cyathium (rarely 2, 3, 4 or 6), flat or shallowly concave, appendages petaloid; styles free at the base, tip bifid or rarely entire; ovary and capsule 
glabrous or pubescent, capsule exserted at maturity; 3-lobed. Seeds ovoid, subglobose, or oblong, more or less 4-angled to rounded; surface smooth or with wart-like protrusions, sometimes distinctively shallowly to deeply pitted, ecarunculate or rarely carunculate.

Distribution and habitat. - Widespread in the New World from Canada to Argentina, with a center of diversity in Mexico and Central America; tropical and subtropical forests, desert scrub, and disturbed areas, sea level to $3000 \mathrm{~m}$.

Included species (115). - E. aaron-rossii A.H. Holmgren \& N.H. Holmgren, E. acerensis Boiss., E. adiantoides Lam., E. alata Hook., E. antisyphilitica Zucc., E. arenaria Kunth, E. ariensis Kunth, E. armourii Millsp., E. arteagae W.R. Buck \& Huft, E. barnesii (Millsp.) Oudejans, E. bicolor Engelm. \& A. Gray, E. bilobata Engelm., E. calcicola Fernald, E. californica Benth., E. caperata McVaugh, E. cassythoides Boiss., E. ceroderma I.M. Johnst., E. chenopodiifolia Boiss., E. colletioides Benth., E. corollata L., E. cotinifolia L., E. curtisii Engelm., E. cymosa Poir., E. defoliata Urb., E. delicatula Boiss., E. dioscoreoides Boiss., E. discoidalis Chapm., E. dugandiana Croizat, E. dwyeri D.G. Burch, E. eglandulosa V.W. Steinm., E. ellipsifolia Gilli, E. ephedromorpha Bartlett ex B.L. Rob. \& Bartlett, E. equisetiformis A. Stewart, E. estevesii N. Zimm. \& P.J. Braun, E. exserta (Small) Coker, E. francoana Boiss., E. fraseri Boiss., E. fulgens Karw. ex Klotzsch, E. gentryi V.W. Steinm. \& T.F. Daniel, E. gradyi V.W. Steinm. \& Ram.-Roa, E. graminea Jacq., E. guadalajarana S. Watson, E. guatemalensis Standl. \& Steyerm., E. guiengola W.R. Buck \& Huft, E. gumaroi J. Meyrán, E. haematantha Boiss., E. henricksonii M.C. Johnst., E. hexagona Nutt. ex Spreng., E. hexagonoides S. Watson, E. hindsiana Benth., E. hintonii L.C. Wheeler, E. humayensis Brandegee, E. innocua L.C. Wheeler, E. insulana Vell., E. ipecacuanhae L., E. ixtlana Huft, E. jablonskii V.W. Steinm., E. lagunensis Huft, E. lancifolia Schltdl., E. leucocephala Lotsy, E. lottiae V.W. Steinm., E. luciismithii B.L. Rob. \& Greenm., E. macropodoides B.L. Rob. \& Greenm., E. macropus (Klotzsch \& Garcke) Boiss., E. macvaughii Carvajal \& Lomelí, E. marginata Pursh, E. mercurialina Michx., E. mexiae Standl., E. misella S. Watson, E. misera Benth., E. monantha C. Wright ex Boiss., E. montereyana Millsp., E. multiseta Benth., E. muscicola Fernald, E. nayarensis V.W. Steinm., E. nephradenia Barneby, E. oaxacana B.L. Rob. \& Greenm., E. ocymoidea L., E. oerstediana (Klotzsch \& Garcke) Boiss., E. oppositifolia McVaugh, E. petiolaris Sims, E. poeppigii (Klotzsch \& Garcke) Boiss., E. polyphylla Engelm. ex Holz., E. pubentissima Michx., E. rossiana Pax, E. rzedowskii McVaugh, E. saccharata Boiss., E. scandens Kunth, E. schlechtendalii Boiss., E. sciadophila Boiss., E. scotanum Schltdl., E. segoviensis (Klotzsch \& Garcke) Boiss., E. sinaloensis Brandegee, E. sonorae Rose, E. soobyi McVaugh, E. sphaerorhiza Benth., E. spruceana Boiss., E. strictior Holz., E. subpeltata S. Watson, E. subreniformis $\mathrm{S}$. Watson, E. subtrifoliata Rusby, E. succedanea L.C. Wheeler, E. surinamensis Lanj., E. tresmariae (Millsp.) Standl., E. tricolor Greenm., E. umbrosa Bertero ex Spreng., E. verapazensis Standl. \& Steyerm., E. violacea Greenm., E. viridis (Klotzsch \& Garcke) Boiss., E. whitei L.C. Wheeler,
E. wrightii Torr. \& A. Gray, E. xalapensis Kunth, E. xanti Engelm. ex Boiss., E. xbacensis Millsp., E. zierioides Boiss.

Discussion. - Section Alectoroctonum is characterized by tiny, mostly glanduliform stipules, petaloid gland appendages, and usually entire leaves. Schlechtendal (1847) coined the genus name Alectoroctonum after the Spanish common name for "rooster killer", presumably referring to the toxicity of the species he assigned to the group.

Due to limited resolution in our analysis, incongruence among markers, and frequent convergence in morphology, additional markers will be required to better resolve relationships within sect. Alectoroctonum. Therefore here we are not proposing any formal subsections, but instead some of the distinct subclades were considered in the discussions.

\section{ACKNOWLEDGEMENTS}

The authors thank V.W. Steinmann, Y. Ramírez-Amezcua, R. Becker, A. Moller, S. Ghazanfar, and the Missouri Botanical Garden for facilitating field work; T.R. van Devender, A.L. Reina-G., V.W. Steinmann, P. Carrillo-Reyes, J.W. Horn, B.W. van Ee, K.J. Wurdack, and B.L. Dorsey for providing plant samples; and curators of the following herbaria who allowed us to sample and examine their specimens: COLO, M, MA, MICH, MO, and UPS. We thank S. Pereira, H. Draheim, B.S. Wagner, D.J. Landau, and B. Oyserman for help with lab work; V.W. Steinmann, J.A. Peirson, J.W. Horn, and B.L. Dorsey for valuable discussion and help revising the manuscript; and P.V. Bruyns and an anonymous reviewer for help improving the manuscript. Funding was provided by the National Science Foundation through a Planetary Biodiversity Inventory award (DEB-0616533) to PEB.

\section{LITERATURE CITED}

Binojkumar, M.S. \& Balakrishnan, N.P. 2010. The genus Euphorbia L. (Euphorbiaceae) in India: A taxonomic revision. New Connaught Place, Dehra Dun, India: Bishen Singh Mahendra Pal Singh.

Boissier, E. 1862. Euphorbiaceae. Pp. 3-188 in: Candolle, A.P. de (ed.), Prodromus systematis naturalis regni vegetabilis. Paris: Victor Masson \& Fils.

Brown, J.M., Hedtke, S.M., Lemmon, A.R. \& Lemmon, E.M. 2010. When trees grow too long: Investigating the causes of highly inaccurate Bayesian branch-length estimates. Syst. Biol. 59: 145-161.

Brown, N.E. 1915. Euphorbia. Pp. 222-375 in: Thistelton-Dyer, W.T. (ed.), Flora Capensis, vol. 5, 2. London: L. Reeve.

Bruyns, P.V. In press. Nomenclature and typification of Southern African species of Euphorbia. Bothalia.

Bruyns, P.V., Klak, C. \& Hanáček, P. 2011. Age and diversity in Old World succulent species of Euphorbia (Euphorbiaceae). Taxon 60: 1717-1733.

Bruyns, P.V., Mapaya, R.J. \& Hedderson, T. 2006. A new subgeneric classification for Euphorbia (Euphorbiaceae) in southern Africa based on ITS and psbA-trnH sequence data. Taxon 55: 397-420.

Carneiro-Torres, D.S., Cordeiro, I., Giulietti, A.M. \& Riina, R. 2012. Euphorbia flaviana, a new species from the inselbergs of Bahia (Brazil) and lectotypification of E. crossadenia. Syst. Bot. 37: 688-693.

Carter, S. 1992. New herbaceous and woody species of Euphorbia (Euphorbiaceae) from Somalia. Nord. J. Bot. 12: 681-688. 
Carter, S. \& Leach, L.C. 2001. Euphorbia. Pp. 339-433 in: Pope, G.V. (ed.), Flora Zambesiaca. Kew: Royal Botanic Gardens, Kew.

Carter, S. \& Radcliffe-Smith, A. 1988. Euphorbiaceae, Tribe Euphorbieae. Pp. 409-564 in: Polhill, R.M. (ed.), Flora of tropical East Africa: Euphorbiaceae, pt. 2. Kew: Royal Botanical Garden, Kew.

Cremers, G. 1984. Les euphorbes coralliformes de Madagascar. Bull. Jard. Bot. Natl. Belg. 54: 23-64.

Croizat, L. 1940. New and critical Euphorbiaceae from eastern tropical Asia. J. Arnold Arbor. 21: 505-506.

Dressler, R.L. 1961. A synopsis of Poinsettia (Euphorbiaceae). Ann. Missouri Bot. Gard. 48: 329-341.

Edgar, R.C., 2004. MUSCLE: Multiple sequence alignment with high accuracy and high throughput. Nucl. Acids Res. 32: 1792-1797.

Haevermans, T. 2003. Le genre Euphorbia L. à Madagascar: Phylogénie moléculaire et systématique. Ph.D. dissertation, Muséum National d'Histoire Naturelle, Paris, France.

Hargreaves, B.J. 1992. The other spurges of Lesotho (at least allegedly). Euphorbia J. 8: 126-132.

Hassall, D.C. 1977. The genus Euphorbia in Australia. Austral. J. Bot. 25: 429-453.

Hayden, W.J. 1988. Ontogeny of the cotyledonary region of Chamaesyce maculata (Euphorbiaceae). Amer. J. Bot. 75: 1701-1713.

Holmgren, A.H. \& Holmgren, N.H. 1988. Euphorbia aaron-rossii (Euphorbiaceae), a new species from Marble and Grand Canyons of the Colorado River, Arizona. Brittonia 40: 357-362.

Horn, J.W., Van Ee, B.W., Morawetz, J.J., Riina, R., Steinmann, V.W., Berry, P.E. \& Wurdack, K.J. 2012a. Phylogenetics and the evolution of major structural characters in the giant genus Euphorbia L. (Euphorbiaceae). Molec. Phylogen. Evol. 63: 305326.

Horn, J.W., Xi, Z., Riina, R., Berry, P.E., Davis, C. \& Wurdack, K.J. 2012b. Evolutionary bursts in the Euphorbia (Euphorbiaceae) Tree of Life are linked with photosynthetic pathway. Abstract 934, Botany 2012, Columbus, Ohio, http://www.botanyconference.org/ engine/search/index.php? func $=$ detail\&aid $=934$.

Huelsenbeck, J.P. \& Ronquist, F. 2001. MRBAYES: Bayesian inference of phylogenetic trees. Bioinformatics 17: 754-755.

Huft, M.J. 1979. A monograph of Euphorbia section Tithymalopsis. Ph.D. dissertation, University of Michigan, Ann Arbor, Michigan, U.S.A.

Huft, M.J. 1984. A review of Euphorbia (Euphorbiaceae) in Baja California. Ann. Missouri Bot. Gard. 71: 1021-1027.

Kolaczkowski, B. \& Thornton, J.W. 2009. Long-branch attraction bias and inconsistency in Bayesian phylogenetics. PLOS ONE 4: e7891, doi:10.1371/journal.pone.0007891.

Koutnik, D.L. 1984. Chamaesyce (Euphorbiaceae) - a newly recognized genus in southern Africa. S. African J. Bot. 3: 262-264.

Koutnik, D.L. 1987. A taxonomic revision of the Hawaiian species of the genus Chamaesyce (Euphorbiaceae). Allertonia 4: 331-388.

Maddison, D.R. \& Maddison, W.P. 2005. MacClade 4.08: An analysis of phylogeny and character evolution. Sunderland, Massachusetts: Sinauer.

Marshall, D.C. 2010. Cryptic failure of partitioned Bayesian phylogenetic analyses: Lost in the land of long trees. Syst. Biol. 59: $108-117$.

Mayfield, M.H. 1997. A systematic treatment of Euphorbia subgenus Poinsettia (Euphorbiaceae). Ph.D. dissertation, the University of Texas at Ausin, Austin, Texas, U.S.A.

Meyrán García, J. 2000. Euphorbia gumaroi Meyrán, una nueva especie del estado de Hidalgo, México. Cact. Suc. Mex. 45: 68-71.

Molero, J. \& Rovira, A.M. 1992. Euphorbia L. subsect. Esula (Boiss. in DC.) Pax in the Iberian Peninsula: Leaf surface, chromosome numbers and taxonomic treatment. Collect. Bot. (Barcelona) 21: $121-181$.

Morawetz, J.J., Wagner, B., Riina, R. \& Berry, P.E. 2010. Euphorbia seed atlas, part 2. Euphorbia World 6(1): 25.
Nylander, J.A.A. 2004. MrModeltest, version 2.3 for Mac. Program distributed by the author. http://www.abc.se/ nylander/ (accessed Jan 2010).

Olmstead, R.G. \& Sweere, J.A. 1994. Combining data in phylogenetic systematics - an empirical approach using three molecular data sets in the Solanaceae. Syst. Biol. 43: 467-481.

Pahlevani, A.H. \& Akhani, H. 2011. Seed morphology of Iranian annual species of Euphorbia (Euphorbiaceae). Bot. J. Linn. Soc. 167: 212-234.

Park, K.R. \& Jansen, R.K. 2007. A phylogeny of Euphorbieae subtribe Euphorbiinae (Euphorbiaceae) based on molecular data. J. Pl. Biol. 50: 644-649.

Pax, F. 1921. Euphorbiaceae. Pp. 1-169 in: Engler, A. (ed.), Vegetation der Erde, vol. 9, Pflanzenwelt Afrikas, vol. 3, pt. 2. Leipzig: Engelmann.

Prenner, G. \& Rudall, P.J. 2007. Comparative ontogeny of the cyathium in Euphorbia (Euphorbiaceae) and its allies: Exploring the organ flower inflorescence boundary. Amer. J. Bot. 94: 16121629.

Prenner, G., Cacho, N.I., Baum, D. \& Rudall, P.J. 2011. Is $L E A F Y$ a useful marker gene for the flower-inflorescence boundary in the Euphorbia cyathium? J. Exp. Bot. 62: 345-350.

Rambaut, A. \& Drummond, A. 2007. Tracer, version 1.4. Computer program and documentation distributed by the author. http://beast .bio.ed.ac.uk/Tracer (accessed 14 Jul 2010).

Rauh, W. \& Mangelsdorff, R.D. 1999. Euphorbia bemarahaensis Rauh \& Mangelsdorff, une nouvelle espèce du groupe Euphorbia bosseri Leandri et Euphorbia platyclada Rauh. Succulentes 21(4): $3-12$.

Riina, R. \& Berry, P.E. (coordinators). 2012 (updated continously). Euphorbia planetary biodiversity inventory database. http://app .tolkin.org/projects/72/taxa (accessed 1 June 2012).

Ronquist, F. \& Huelsenbeck, J.P. 2003. MrBayes 3: Bayesian phylogenetic inference under mixed models. Bioinformatics 19: 1572 1574.

Sage, T.L., Sage, R.F., Vogan, P.J., Rahman, B., Johnson, D.C., Oakley, J.C. \& Heckel, M.A. 2011. The occurrence of $\mathrm{C}_{2}$ photosynthesis in Euphorbia subgenus Chamaesyce (Euphorbiaceae). J. Exp. Bot. 62: 3183-3195.

Schill, R. 1971. Cytotaxonomische Untersuchungen an sukkulenten Vertretern der Gattung Euphorbia L. aus Madagaskar. Ber. Deutsch. Bot. Ges. 84: 71-78.

Schlechtendal, D.F.L. von 1847. Plantae Leiboldianae. Dicotyleae. Linnaea 19: 234-320.

Shaw, J., Lickey, E.B., Schilling, E.E. \& Small, R.L. 2007. Comparison of whole chloroplast genome sequences to choose noncoding regions for phylogenetic studies in angiosperms: The tortoise and the hare III. Amer. J. Bot. 94: 275-288.

Simmons, M.P. 2004. Independence of alignment and tree search. Molec. Phylogen. Evol. 31: 874-879.

Simmons, M.P. \& Hayden, W.J. 1997. Revision of the cerrado hemicryptophytic Chamaesyce of Boissier's "Pleiadeniae" (Euphorbiaceae). Brittonia 49: 155-180.

Stamatakis, A., 2006. RAxML-VI-HPC: Maximum likelihood-based phylogenetic analyses with thousands of taxa and mixed models. Bioinformatics 22: 2688-2690.

Steinmann, V.W. \& Porter, J.M. 2002. Phylogenetic relationships in Euphorbieae (Euphorbiaceae) based on ITS and $n d h F$ sequence data. Ann. Missouri Bot. Gard. 89: 453-490.

Swofford, D.L. 2003. PAUP*: Phylogenetic analysis using parsimony (*and other methods), version 4. Sunderland, Massachusetts: Sinauer.

Thulin, M. \& Al-Gifri, A.N. 1995. Euphorbia applanata sp. nov. (Euphorbiaceae) from Yemen, with a note on E. quaitensis. Nord. J. Bot. 15: 193-195.

Ward, D.B. 2001. New combinations in the Florida flora. Novon 11: $360-365$. 
Webster, G.L. 1967. The genera of Euphorbiaceae in the southeastern United States. J. Arnold Arbor. 48: 303-430.

Webster, G.L., Brown, W.V. \& Smith, B.N. 1975. Systematics of photosynthetic carbon fixation pathways in Euphorbia. Taxon 24: 27-33.

Wheeler, L.C. 1941. Euphorbia subgenus Chamaesyce in Canada and the United States exclusive of Southern Florida. Rhodora 43: 97-154, 168-205, 223-286, pls. 654-668.

Wheeler, L.C. 1943. The genera of the living Euphorbieae. Amer. Midland Naturalist 30: 456-503.
Yang, Y. \& Berry, P.E. 2011. Phylogenetics of the Chamaesyce clade (Euphorbia, Euphorbiaceae): Reticulate evolution and longdistance dispersal in a prominent $\mathrm{C}_{4}$ lineage. Amer. J. Bot. 98: $1486-1503$.

Zimmermann, N.F.A., Ritz, C.M. \& Hellwig, F.H. 2010. Further support for the phylogenetic relationships within Euphorbia L. (Euphorbiaceae) from nrITS and trnL-trnF IGS sequence data. Pl. Syst. Evol. 286: 39-58.

Appendix. Specimens used in this study.

Taxon, collector, and collection number (herbarium acronym), collection locality, and GenBank accession numbers for ITS and $n d h F$ sequences, respectively. Sequences without collection information were downloaded from GenBank.

Euphorbia aaron-rossii A.H. Holmgren \& N.H. Holmgren, AF537396, -; Euphorbia acanthothamnos Heldr. \& Sart. ex Boiss., Riina 1563 (MICH), Greece: Crete, JQ750879, JQ750756; Euphorbia acerensis Boiss., Van Ee 648 (MICH, SI, US), Argentina: Córdoba, JQ750872, JQ750757; Euphorbia acuta Engelm., AF537450, AF538176; Euphorbia adiantoides Lam., AF537395,-; Euphorbia aequoris N.E. Br. 1, Becker 1167 (MICH, PRE, UNIN), South Africa: Western Cape, JQ750873, JQ750758; Euphorbia aequoris N.E. Br. 2, Becker 1277 (MICH, PRE, UNIN), South Africa: Northern Cape, JQ750874, JQ750759; Euphorbia agowensis Hochst. ex Boiss., AF537419, -; Euphorbia alata Hook., Campbell s.n. (FTG), U.S.A.: cultivated at Fairchild Tropical Botanical Garden, \#2009-0138, originally from Jamaica: Cockpit country, JQ750875, JQ750760; Euphorbia albipollinifera L.C. Leach, Marx 209 (from the field, MA) and Riina 1611 (from living collection, MICH), Netherlands: private living collection of R. van Veldhuisen, originally from South Africa: Eastern Cape, JQ750870, JQ750761; Euphorbia albomarginata Torr. \& A. Gray, Reina-G. 2006-389 (MICH), Mexico: Sonora, HQ645221, JQ750762; Euphorbia angusta Engelm., Yang 41 (MICH), U.S.A.: Texas, HQ645222, JQ750763; Euphorbia antisyphilitica Zucc., Yang 8 (MICH), U.S.A.: Texas, JQ750876, JQ750764; Euphorbia appariciana Rizzini, Caruzo 138 (HUEFS), Brazil: Bahia, JQ750877, JQ750765; Euphorbia arceuthobioides Boiss., AM040758, -; Euphorbia ariensis Kunth, AF537409, -; Euphorbia arteagae W.R. Buck \& Huft, Steinmann 2354 (MICH), Mexico, JQ750878, JQ750766; Euphorbia barbicollis P.R.O. Bally, Horn s.n. (Arid Lands Nursery), U.S.A.: Cultivated at Arid Lands Nursery, Tucson, Arizona, originally from Somalia., JQ750881, JQ750767; Euphorbia beharensis Leandri, Yang 188 (MICH), U.S.A.: Cultivated at Fairchild Tropical Botanical Garden, \#2006-1173*A, originally from Madagascar, JQ750890, JQ750768; Euphorbia bemarahaensis Rauh \& R. Mangelsdorff, AJ508984, -; Euphorbia bicolor Engelm. \& A. Gray, AF537386, -; Euphorbia bifurcata Engelm., AF537434, AF538173; Euphorbia bilobata Engelm., Van Devender 2007-1036 (MICH), Mexico: Sonora, JQ750882, JQ750769; Euphorbia brachiata (E. Mey ex Klotzsch \& Garcke) Boiss., Morawetz. 280 (MICH), South Africa: Western Cape, JQ750883, JQ750770; Euphorbia breviarticulata Pax, Morawetz 375 (EA, MICH, MO), Kenya, JQ750885, JQ750771; Euphorbia burmannii (Klotzsch \& Garcke) E. Mey. ex Boiss. 1, Morawetz 266 (MICH, NBG), South Africa: Eastern Cape, JQ750884, JQ750772; Euphorbia burmannii (Klotzsch \& Garcke) E. Mey. ex Boiss. 2, Becker 873 (PRE, UNIN), South Africa: Western Cape, JQ750933, JQ750823; Euphorbia calcicola Fernald, AF537385, -; Euphorbia californica Benth., Sanchez 06-050 (MICH), Mexico: Sonora, JQ750892, JQ750773; Euphorbia caperata McVaugh, Steinmann 5891 (IEB), Mexico, JQ750893, JQ750774; Euphorbia capitellata Engelm., Reina-G. 2006-539 (MICH), Mexico: Sonora, HQ645237, JQ750775; Euphorbia cassythoides Boiss., AF537387, -; Euphorbia caterviflora N.E. Br., Becker 1126 (MICH, PRE, UNIN), South Africa: Northern Cape, JQ750894, JQ750776; Euphorbia celastroides Boiss., Berry 7864 (MICH), U.S.A.: cultivated at the Huntington Botanical Gardens, California, originally from U.S.A.: Hawaii, JQ750895, JQ750777; Euphorbia ceroderma I.M. Johnst., AF537389, AF538153; Euphorbia cheirolepis Fisch. \& C.A. Mey. ex Karelin, AF537424, -; Euphorbia chersina N.E. Br., Becker 903 (PRE, UNIN), South Africa: Northern Cape, JQ750896, JQ750778; Euphorbia chersonesa Huft, AF537436, AF538174; Euphorbia colletioides Benth., Reina-G. 2006-1314 (MICH), Mexico: Sonora, JQ750897, JQ750779; Euphorbia colorata Engelm., Van Devender 2006-1031 (MICH), Mexico: Sonora, JQ750898, JQ750780; Euphorbia cornastra (Dressler) Radcl.-Sm., Berry 7840 (MICH), U.S.A.: cultivated at the Ecke Ranch, Encinitas, California, JQ750899, JQ750781; Euphorbia corollata L., Berry 7764 (MICH), U.S.A.: Indiana, JQ750900, JQ750782; Euphorbia cotinifolia L., Riina 1587 (VEN), Venezuela: Edo. Vargas, JQ750901, JQ750783; Euphorbia crossadenia Pax \& K. Hoffm., Giulietti 2417 (HUEFS), Brazil: Bahia, JQ750902, -; Euphorbia crotonoides subsp. crotonoides Boiss., Morawetz 456 (DSM, K, MICH, MO, NHT), Tanzania: Rukwa Region, JQ750871, JQ750784; Euphorbia cuphosperma (Engelm.) Boiss., Yang 44 (MICH, IEB), Mexico: Guanajuato, JQ750903, JQ750785; Euphorbia cyathophora Murray, Yang 129 (MICH), U.S.A.: Florida, JQ750904, JQ750786; Euphorbia cymosa Poir., Van Ee 761 (MICH), Jamaica: St. Andrew, JQ750905, JQ750787; Euphorbia delicatula Boiss., AF537393, AF538152; Euphorbia denisii Oudejans, Dorsey 184 (MICH, TAN, MO), Madagascar: Toliara, -, JQ750788; Euphorbia dentata Michx., Van Ee 627 (MICH, SI, US), Argentina: Córdoba, JQ750906, JQ750789; Euphorbia dioscoreoides subsp. attenuata V.W. Steinm., Reina-G. 2006-562 (MICH), Mexico: Sonora, JQ750907, JQ750790; Euphorbia eglandulosa V.W. Steinm., AF537394, -; Euphorbia einensis G. Will., Becker 911 (PRE, UNIN), South Africa: Northern Cape, JQ750908, JQ750791; Euphorbia ephedroides E. Mey. ex Boiss., Becker 908 (PRE, UNIN), South Africa: Northern Cape, JQ750909, JQ750792; Euphorbia equisetiformis A. Stewart, AF537388, -; Euphorbia eriantha Benth., AF537440, AF538167; Euphorbia espinosa Pax, AF537416, AF538190; Euphorbia exilis L.C. Leach 1, AM040767, -; Euphorbia exilis L.C. Leach 2, Becker 894 (PRE, UNIN), South Africa: Northern Cape, JQ750913, JQ750798; Euphorbia exstipulata Engelm., Reina-G. 2006-674 (MICH), Mexico: Sonora, JQ750910, JQ750793; Euphorbia flaviana Carneiro-Torres \& Cordeiro, AF537457, -; Euphorbia florida Engelm., Reina-G. 2006-476 (MICH), Mexico: Sonora, HQ645268, JQ750794; Euphorbia francoana Boiss., Steinmann 2083 (MICH), Mexico: Michoacan, JQ750911, JQ750795; Euphorbia fulgens Karw. ex Klotzsch, AF537404, AF538154; Euphorbia gentilis N.E. Br., Becker 1188 (MICH, PRE, UNIN), South Africa: Western Cape, JQ750912, JQ750796; Euphorbia gentryi V.W. Steinm. \& T.F. Daniel, AF537406,-; Euphorbia giessii L.C. Leach, Becker 1366 (WIND, MICH, PRE, UNIN), Namibia: Erongo, -, JQ750797; Euphorbia glanduligera Pax, AF537426, AF538178; Euphorbia goetzei Pax, AF537413, AF538185; Euphorbia goyazensis Boiss., Caruzo 139 (HUEFS), Brazil: Bahia, JQ750914, JQ750799; Euphorbia gradyi V.W. Steinm. \& Ram.-Roa, AF537407, AF538151; Euphorbia graminea Jacq. 1, Berry 7843 (MICH), U.S.A.: cultivated at the Ecke Ranch, Encinitas, California, JQ750915, JQ750800; Euphorbia graminea Jacq. 2, Christenhusz 3297 (MICH), Jamaica, JQ750945, JQ750801; Euphorbia guadalajarana S. Watson, Carrillo-Reyes 5902 (IEB), Mexico: Jalisco, JQ750916, JQ750802; Euphorbia guatemalensis Standl. \& Steyerm., AF537408, -; Euphorbia gueinzii Boiss., Hobson 2141 (PRE), Swaziland, JQ750917, JQ750803; Euphorbia guerichiana Pax, Becker 929 (PRE, UNIN), South Africa: Northern Cape, JQ750918, JQ750804; Euphorbia guiengola W.R. Buck \& Huft, Berry 7753 (MICH), U.S.A.: cultivated at the green house of UC-Davis, California, \#B76.047, JQ750919, JQ750805; Euphorbia gumaroi J. Meyrán, Steinmann 5813 (MICH, IEB), Mexico: Hidalgo, JQ750920, JQ750806; Euphorbia gymnoclada Boiss., Caruzo 130 (HUEFS), Brazil: Bahia, JQ750921, JQ750807; Euphorbia gymnonota Boiss., Yang 185 (MICH), U.S.A.: Cultivated, JQ750886, JQ750808; Euphorbia hainanensis Croizat, Gilbert 501 (MO, K), China: Hainan, JQ750922, -; Euphorbia helioscopia L., Riina 1607 (MICH), Spain: Castilla y Leon, JQ750880, JQ750809; Euphorbia herrei A.C. White, R.A. Dyer \& B. Sloane, Becker 937 (PRE, UNIN), South Africa: Northern Cape, JQ750923, JQ750810; Euphorbia heterophylla L., Riina 1596 (VEN), Venezuela: Barinas, JQ750924, JQ750811; Euphorbia hexagona Nutt. ex Spreng., Clark 1793 (COLO), U.S.A.: Colorado, JQ750925, JQ750812; Euphorbia hindsiana Benth., Steinmann 6438 (IEB, MICH), Mexico: Baja California Sur, JQ750926, JQ750813; Euphorbia hinkleyorum I.M. Johnst., Carrillo-Reyes 5963 (CORD), Argentina: Jujuy, JQ750887, JQ750814; Euphorbia hirta L., Reina-G. $2006-470$ (MICH), Mexico: Sonora, HQ645278, JQ750815; Euphorbia hormorrhiza Radcl.-Sm., AF537431, AF538165; Euphorbia humayensis Brandegee, Steinmann 1153 (MICH), Mexico: Sinaloa, JQ750927, JQ750816; Euphorbia humifusa Willd., Schuhwerk 06/511 (MICH), Germany: Oberpfalz, JQ750928, JQ750817; 
Appendix. Continued.

Euphorbia hyssopifolia L., Van Devender 2006-463 (MICH), Mexico: Sonora, HQ645283, JQ750818; Euphorbia innocua L.C. Wheeler, AF537380, AF538161; Euphorbia insulana Vell., Riina 1586 (VEN), Venezuela: Dtto. Federal, JQ750930, JQ750819; Euphorbia ipecacuanhae L., AF537397, -; Euphorbia ixtlana Huft, Carrillo-Reyes 5555 (IEB, MICH), Mexico: Oaxaca, JQ750931, JQ750820; Euphorbia jaliscensis B.L. Rob. \& Greenm., AF537442, AF538166; Euphorbia juttae Dinter 1, AF537418, AF538188; Euphorbia juttae Dinter 2, Becker 1402 (WIND, MICH, PRE, UNIN), Namibia: Karas, JQ750932, JQ750821; Euphorbia kabridarensis Thulin, Thulin 11585 (UPS), Ethiopia: Somali National Regional State, -, JQ750822; Euphorbia lacera Boiss., AF537441, -; Euphorbia lagunensis Huft, AF537379, -; Euphorbia leistneri R.H. Archer, Morawetz 303 (MICH), South Africa, JQ750934, JQ750824; Euphorbia leucocephala Lotsy, Yang 125 (MICH), U.S.A.: Florida, JQ750935, JQ750825; Euphorbia lumbricalis L.C. Leach, AM040779, -; Euphorbia lycioides Boiss., Farias Castro 2030 (EAC), Brazil: Piaui, JQ750936, JQ750826; Euphorbia macropodoides B.L. Rob. \& Greenm., Anderson 4840 (MICH), Mexico: Oaxaca, JQ750937, JQ750827; Euphorbia macropus (Klotzsch \& Garcke) Boiss., Van Devender 2006-1033 (MICH), Mexico: Sonora, JQ750938, JQ750828; Euphorbia maculata L., Schuhwerk 6/598 (M), JQ750939, JQ750829; Euphorbia macvaughii Carvajal \& Lomelí, AF537382, -; Euphorbia marginata Pursh, AJ534787, AJ534788, EU022037; Euphorbia mexiae Standl., Carrillo-Reyes 5800 (MICH), Mexico: Jalisco, JQ750942, JQ750831; Euphorbia misella S. Watson, AF537384, AF538160; Euphorbia misera Benth., AF537383, EU022036; Euphorbia mundii N.E. Br., Becker 1147 (MICH, PRE, UNIN), South Africa: Western Cape, JQ750943, JQ750832; Euphorbia oaxacana B.L. Rob. \& Greenm., AF537373, -; Euphorbia ocymoidea L., Van Devender $2007-1346$ (MICH), Mexico, JQ750944, JQ750833; Euphorbia oerstediana Klotzsch \& Garcke Boiss., -, AF538159; Euphorbia parvicaruncula D.C. Hassall, AJ534809+AJ534810, -; Euphorbia pediculifera Engelm., Reina-G. 2006-483 (MICH), Mexico: Sonora, JQ750946, JQ750834; Euphorbia pentadactyla Griseb., AF537428, -; Euphorbia pervilleana Baill., Dorsey 188 (MICH, TAN, MO), Madagascar: Toliara, JQ750888, JQ750835; Euphorbia petiolata Banks \& Sol., AF537422, AF538180; Euphorbia phosphorea Mart., Caruzo 145 (HUEFS), Brazil: Bahia, JQ750889, JQ750836; Euphorbia phylloclada Boiss., AF537427, AF538179; Euphorbia pinetorum (Small) G.L. Webster, Yang 168 (MICH), U.S.A.: Florida, JQ750947, JQ750837; Euphorbia pirottae N. Terrac., AF537417, AF538186; Euphorbia plagiantha Drake, Dorsey 164 (MICH, TAN, MO), Madagascar: Toliara,-, JQ750838; Euphorbia planiticola D.C. Hassall, Gillespie 7324 (MICH), Australia: New South Wales, -, JQ750839; Euphorbia platyclada Rauh, AF537421, AF538187; Euphorbia poeppigii (Klotzsch \& Garcke) Boiss., AJ534793+AJ534794, -; Euphorbia polyantha Pax, -, EU022107; Euphorbia polygonifolia L., Berry 7765 (MICH), Canada: Ontario, JQ750948, JQ750840; Euphorbia polyphylla Engelm. ex Holz., Yang 0158 (MICH), U.S.A.: Florida, JQ750949, JQ750841; Euphorbia pulcherrima Willd. ex Klotzsch, Van Devender 2007-1177 (MICH), Mexico, JQ750950, JQ750842; Euphorbia pumicicola Huft, AF537437, AF538164; Euphorbia quaitensis S. Carter, -, EU022061; Euphorbia radians Benth., AF537438, AF538169; Euphorbia rhombifolia Boiss. 1, AF537414, AF538183; Euphorbia rhombifolia Boiss. 2, Becker 864 (PRE, UNIN), South Africa: Western Cape, JQ750929, JQ750843; Euphorbia rhombifolia Boiss. 3, Becker 1105 (MICH, PRE, UNIN), South Africa: Eastern Cape, JQ750951, JQ750844; Euphorbia rossiana Pax, AF537374, -; Euphorbia royleana Boiss., Berry 7739 (MICH), U.S.A.: Cultivated, JQ750891, JQ750845; Euphorbia rzedowskii McVaugh, AF537399, -; Euphorbia salota Leandri, Aubriot 28 (P, MICH), Madagascar: Androy, JQ750952, JQ750846; Euphorbia sarcodes Boiss., Caruzo 141 (HUEFS), Brazil: Bahia, JQ750953, JQ750847; Euphorbia scandens Kunth, Carrillo-Reyes 5146 (IEB, MICH), Mexico: Chiapas, JQ750954, JQ750848; Euphorbia scatorhiza S. Carter, AF537420, AF538181; Euphorbia schlechtendalii Boiss., Steinmann 2172 (MICH, IEB), Mexico: Michoacan, JQ750955, JQ750849; Euphorbia sciadophila Boiss., Van Ee 650 (MICH, SI, US), Argentina: Córdoba, JQ750956, JQ750850; Euphorbia segoviensis (Klotzsch \& Garcke) Boiss., AF537400, -; Euphorbia sessilifolia Klotzsch ex Boiss., Caruzo 133 (HUEFS), Brazil: Bahia, JQ750957, JQ750851; Euphorbia setiloba Engelm. ex Torr., Reina-G. 2006-478 (MICH), Mexico: Sonora, HQ645345, JQ750852; Euphorbia setosa (Boiss.) Müll.Arg., Cordeiro 3025 (SP), Brazil: Minas Gerãis, HQ645346, JQ750853; Euphorbia sinaloensis Brandegee, AF537401, AF538156; Euphorbia sonorae Rose, Reina-G. 2006-830 (MICH), Mexico: Sonora, JQ750958, JQ750854; Euphorbia soobyi McVaugh, Carrillo-Reyes 5895 (MICH), Mexico: Jalisco, JQ750959, JQ750855; Euphorbia sp. nov. 1, Ramírez-Amezcua 1428 (MICH, IEB), Mexico: Michoacán, JQ750962, JQ750856; Euphorbia sp. nov. 2, Steinmann 6586 (IEB), Mexico: Michoacán, JQ750960, JQ750857; Euphorbia sp. nov. 3, Van Devender 2006-1030 (MICH), Mexico: Sonora, JQ750961, JQ750858; Euphorbia sp. nov. 4, Linneo 1053 (MO), Bolivia: Santa Cruz, JQ750940, JQ750830; Euphorbia sp. nov. 5, Steinmann 5833 (IEB), Mexico: Querétaro, JQ750970, JQ750869; Euphorbia spartaria N.E. Br., Becker 1370 (WIND, MICH, PRE, UNIN), Namibia: Khomas, -, JQ750859; Euphorbia sphaerorhiza Benth. 1, Yang 110 (MICH, IEB), Mexico: Michoacán, JQ750963, JQ750860; Euphorbia sphaerorhiza Benth. 2, Breedlove 63154 (MICH), Mexico: Durango, JQ750941, JQ750861; Euphorbia spinea N.E. Br., Becker 967 (PRE, UNIN), South Africa: Northern Cape, JQ750964, JQ750862; Euphorbia stapelioides Boiss., AM040790, -; Euphorbia strigosa Hook. \& Arn., AF537439, AF538163; Euphorbia subpeltata S. Watson, Ramirez-Amezcua 1129 (IEB), Mexico, JQ750965, JQ750863; Euphorbia subreniformis S. Watson, Van Devender 2006-1003 (MICH), Mexico: Sonora, JQ750966, JQ750864; Euphorbia succedanea L.C. Wheeler, AF537403, AF538162; Euphorbia suffulta Bruyns, AM040794, -; Euphorbia tannensis subsp. tannensis Spreng., AF537425, AF538184; Euphorbia tannensis subsp. eremophila (A. Cunn. ex Hook.) D.C. Hassall, AF537423, -; Euphorbia thymifolia L., Van Devender 2006-628 (MICH), Mexico: Sonora, JQ750967, JQ750865; Euphorbia tresmariae (Millsp.) Standl., Steinmann 1089 (MICH, RSA), Mexico: Jalisco, JQ750968, JQ750866; Euphorbia whitei L.C. Wheeler, AF537391, -; Euphorbia xalapensis Kunth, Steinmann 4221 (MICH, IEB), Mexico: Michoacan, -, JQ750867; Euphorbia xanti Engelm. ex Boiss., Yang 0199 (IEB, MICH), Mexico: Baja California Sur, JQ750969, JQ750868; Euphorbia zonosperma Müll. Arg., AF537430, -. 